\title{
Klyflaccicembranols A-I, New Cembranoids from the Soft Coral Klyxum flaccidum
}

\author{
Atallah F. Ahmed ${ }^{1,2,3}$, Chia-Ruei Tsai ${ }^{1}$, Chiung-Yao Huang ${ }^{1}$, Sheng-Yang Wang ${ }^{4}$ and \\ Jyh-Horng Sheu $1,5,6,7,8, *$
}

1 Department of Marine Biotechnology and Resources, National Sun Yat-sen University, Kaohsiung 80424, Taiwan; afahmed@ksu.edu.sa (A.F.A.); qse456awd@gmail.com (C.-R.T.);

huangcy@mail.nsysu.edu.tw (C.-Y.H.)

2 Department of Pharmacognosy, College of Pharmacy, King Saud University, Riyadh 11451, Saudi Arabia

3 Department of Pharmacognosy, Faculty of Pharmacy, Mansoura University, Mansoura 35516, Egypt

4 Department of Forestry, National Chung Hsing University, Taichung 40227, Taiwan; taiwanfir@dragon.nchu.edu.tw

5 Institute of Natural Products, Kaohsiung Medical University, Kaohsiung 80756, Taiwan

6 Department of Medical Research, China Medical University Hospital, China Medical University, Taichung 40402, Taiwan

7 Frontier Center for Ocean Science and Technology, National Sun Yat-sen University, Kaohsiung 80424, Taiwan

8 Doctoral Degree Program in Marine Biotechnology, National Sun Yat-sen University, Kaohsiung 80424, Taiwan

* Correspondence: sheu@mail.nsysu.edu.tw; Tel.: +886-7-5252-000 (ext. 5030)

Academic Editor: Kirsten Benkendorff

Received: 19 December 2016; Accepted: 16 January 2017; Published: 21 January 2017

\begin{abstract}
New cembranoids klyflaccicembranols A-I (1-9), along with gibberosene D (10), have been isolated from the organic extract of a Formosan soft coral Klyxum flaccidum. Their structures were established by extensive spectroscopic analyses, including 2D NMR spectroscopy, and spectral data comparison with related structures. The cytotoxicity of the isolated metabolites, as well as their nitric oxide (NO) inhibitory activity, were evaluated and reported. Metabolites 2, 4, 6, 8 and 9 were found to exhibit variable activities against a limited panel of cancer cell lines in a range of $\mathrm{IC}_{50} 16.5-49.4 \mu \mathrm{M}$. Among the tested cembranoids, compounds 4, 5, 6, and 9 significantly inhibited NO production in lipopolysaccharide (LPS)-stimulated RAW264.7 macrophages at a dose of $50 \mu \mathrm{g} / \mathrm{mL}$.
\end{abstract}

Keywords: soft coral; Klyxum flaccidum; cembranoid; NO inhibition; cytotoxicity

\section{Introduction}

The marine environment has long been recognized as an exceptional source of new natural products with a diverse range of chemical structures and bioactivities, including anti-cancer, antiviral, immunosuppressive and anti-inflammatory activities [1-3]. This structural diversity has supplied unique chemicals for the pharmaceutical, cosmetics, and even agrochemicals industry [4]. Soft corals belonging to the genus Klyxum (Alcyoniidae), including Klyxum flaccidum, are considered rich sources of eunicellin-based diterpenoids species [2,5-10], of which many compounds have been found to exert anti-inflammatory [7-10] and cytotoxic [8,11] effects. A series of cytotoxic and anti-inflammatory steroids was also discovered from $K$. flaccidum in our previous investigations [12,13]. Cembranoid-based diterpenoids have not hitherto been isolated from soft corals of the genus Klyxum. However, our continuing investigation into the chemical constituents of a Formosan soft coral K. flaccidum has led to the discovery of a series of new polyoxygenated cembranoids. Extensive spectroscopic analyses, including 2D NMR spectroscopy and spectral comparison, were applied 
to establish the structures of these new metabolites. The cytotoxicity of the isolated metabolites was further assessed against a limited panel of cancer cell lines via Alamar Blue assay [14,15], and anti-inflammatory activity was evaluated in terms of their potential to inhibit nitric oxide (NO) production in lipopolysaccharide (LPS)-stimulated RAW264.7 macrophages.

\section{Results and Discussion}

Sliced bodies of the soft coral K. flaccidum were extracted exhaustively with ethyl acetate (EtOAc). The solvent-free extract was then fractionated over a silica gel 60 column to yield 26 fractions. Fractions that displayed terpenoidal methyl, olfeinic and oxymethine proton signals in the ${ }^{1} \mathrm{H}$ NMR spectrum were selected and further purified using a successive series of silica gel 60 and RP-18 gel columns to yield compounds 1-10 (Figure 1).

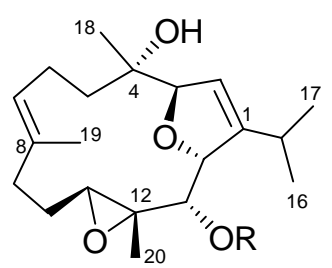

1: $\mathrm{R}=\mathrm{H}$

8: $R=A C$<smiles>CC1=CCC[C@](C)(O)C=CC[C@@](C)(O)C=CC(C(C)C)=C1</smiles>

4

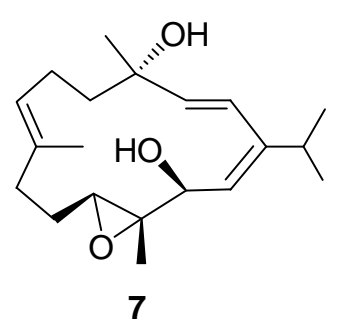

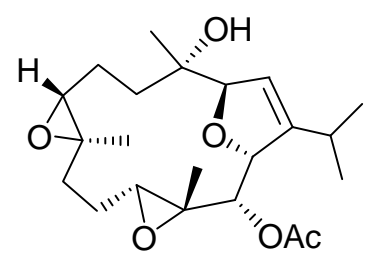

2<smiles>CC/C(C)=C/CC/C=C(\C)C[C@H](O)/C(=C\[C@@H](O)C(C)(C)O)C(C)C</smiles>

5

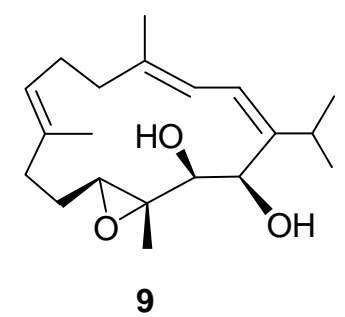

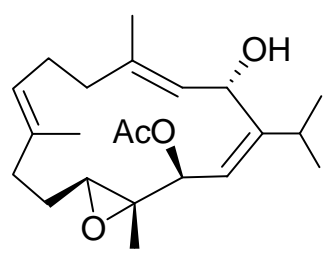

3

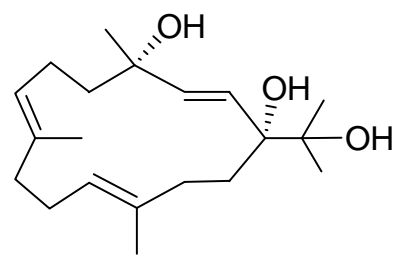

6

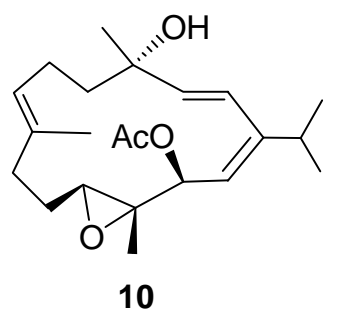

Figure 1. Structures of cembranoids isolated from Klyxum flaccidum.

Klyflaccicembranol A (1) was isolated as a colorless oil. Its molecular formula $\mathrm{C}_{20} \mathrm{H}_{32} \mathrm{O}_{4}$ was deduced from the sodium adduct ion peak $\left(\mathrm{m} / z 359.2196[\mathrm{M}+\mathrm{Na}]^{+}\right)$in the high-resolution electrospray ionization mass spectrometry (HRESIMS) and NMR data measured in $\mathrm{C}_{6} \mathrm{D}_{6}$ (Tables 1 and 2). Thus, five degrees of unsaturation were indicated. The infrared (IR) absorption band at $v_{\max } 3445 \mathrm{~cm}^{-1}$ revealed the presence of hydroxy functionality. The ${ }^{13} \mathrm{C}$ NMR spectrum displayed 20 carbon signals (Table 1), which were characterized by distortionless enhancement by polarization transfer (DEPT) and heteronuclear single-quantum correlation (HSQC) spectra as five methyls, four methylenes, seven methines (including two olfeinic and four $s p^{3}$ oxymethines), and four nonprotonated carbons (including two olfeinic and two $s p^{3}$ oxycarbons). The NMR signals at $\delta_{C}$ 147.8, C; 132.1, C; 127.0, CH and 121.0, $\mathrm{CH} ; \delta_{\mathrm{H}} 5.59,1 \mathrm{H}$, br s and $5.38,1 \mathrm{H}, \mathrm{dd}, J=5.2,5.2 \mathrm{~Hz}$ indicated the presence of two trisubstituted double bonds. Thus, the remaining three unsaturations suggested 1 to be a tricyclic diterpenoid. However, it was found that the NMR data of 1 differed from those of eunicellins discovered from Klyxum species [2,5-10] and resembled those of cembranoids isolated from Sinularia and Sarcophyton 
species [16-18], as no correlation spectroscopy (COSY) correlated ring-juncture $s p^{3}$ methine protons were detected in 1 . One trisubstituted epoxide $\left(\delta_{\mathrm{C}} 61.9, \mathrm{C}\right.$ and $59.7, \mathrm{CH} ; \delta_{\mathrm{H}} 3.15,1 \mathrm{H}, \mathrm{dd}, \mathrm{J}=6.4$, $2.0 \mathrm{~Hz})$ and an ether bridge $\left(\delta_{\mathrm{C}} 89.7, \mathrm{CH} ; \delta_{\mathrm{H}} 4.61,1 \mathrm{H}, \mathrm{d}, J=4.8 \mathrm{~Hz}\right.$ and $\delta_{\mathrm{C}} 85.8, \mathrm{CH} ; \delta_{\mathrm{H}} 4.78,1 \mathrm{H}, \mathrm{br} \mathrm{d}$, $J=4.8 \mathrm{~Hz}$ ) of a 2,3,5-trisubstituted dihydrofuran moiety [18] were also deduced. Thus, the remaining two oxygen atoms of the molecular formula were ascribed to two hydroxy groups linked to the carbon atoms resonating at $72.8(\mathrm{CH})$ and $74.2(\mathrm{C})$. Analysis of the COSY correlations of 1 indicated the presence of four proton-correlated partial structures, including those of an isopropyl group (Figure 2). By analysis of heteronuclear multiple bond correlation (HMBC) correlations observed from the methyl, olfeinic, and oxymethine protons, it was possible to connect the four partial structures and to assign the positions of the two hydroxy groups, one trisubstituted double bond, and a trisubstituted epoxide at C-4, C-13, C-7/C-8, and C-11/C-12, respectively (Figure 2). The ether linkage of the dihydrofuran was confirmed by the HMBC correlations found from H-2 $\left(\delta_{\mathrm{H}} 5.59\right.$, br s) to C-1 $\left(\delta_{\mathrm{C}} 147.8, \mathrm{C}\right), \mathrm{C}-3\left(\delta_{\mathrm{C}} 89.7\right.$, $\mathrm{CH})$ and $\mathrm{C}-14\left(\delta_{\mathrm{C}} 85.8, \mathrm{CH}\right)$ and from $\mathrm{H}-14\left(\delta_{\mathrm{H}} 4.78, \mathrm{br} \mathrm{d}, J=4.8 \mathrm{~Hz}\right)$ to $\mathrm{C}-3$, respectively. The planar structure of compound 1 was thus established as 4,13-dihydroxy-3,14:11,12-bisepoxy-cembra-1,7-diene.

Table 1. ${ }^{13} \mathrm{C}$ NMR spectral data of compounds 1-9.

\begin{tabular}{|c|c|c|c|c|c|c|c|c|c|}
\hline$\#$ & $1^{a}$ & $2^{b}$ & $3^{c}$ & $4^{a}$ & $5^{c}$ & $6^{b}$ & $7^{c}$ & $8^{c}$ & $9^{a}$ \\
\hline 1 & $147.8(\mathrm{C})$ & $147.7(\mathrm{C})$ & $155.9(\mathrm{C})$ & $146.3(\mathrm{C})$ & $154.6(\mathrm{C})$ & $80.9(\mathrm{C})$ & $146.0(\mathrm{C})$ & $147.4(\mathrm{C})$ & $146.9(\mathrm{C})$ \\
\hline 2 & $121.0(\mathrm{CH})^{d}$ & $121.2(\mathrm{CH})$ & $67.2(\mathrm{CH})$ & $124.3(\mathrm{CH})$ & $122.7(\mathrm{CH})$ & $129.2(\mathrm{CH})$ & $123.7(\mathrm{CH})$ & $121.2(\mathrm{CH})$ & $120.8(\mathrm{CH})$ \\
\hline 3 & 89.7 (CH) & $91.1(\mathrm{CH})$ & $126.3(\mathrm{CH})$ & $136.2(\mathrm{CH})$ & $70.7(\mathrm{CH})$ & $138.0(\mathrm{CH})$ & $138.3(\mathrm{CH})$ & $89.1(\mathrm{CH})$ & $121.0(\mathrm{CH})$ \\
\hline 5 & $41.6\left(\mathrm{CH}_{2}\right)$ & $40.5\left(\mathrm{CH}_{2}\right)$ & $39.0\left(\mathrm{CH}_{2}\right)$ & $45.5\left(\mathrm{CH}_{2}\right)$ & $38.6\left(\mathrm{CH}_{2}\right)$ & $43.8\left(\mathrm{CH}_{2}\right)$ & $39.0\left(\mathrm{CH}_{2}\right)$ & $41.3\left(\mathrm{CH}_{2}\right)$ & $39.1\left(\mathrm{CH}_{2}\right)$ \\
\hline 6 & $22.1\left(\mathrm{CH}_{2}\right)$ & $25.2\left(\mathrm{CH}_{2}\right)$ & $24.2\left(\mathrm{CH}_{2}\right)$ & $121.3(\mathrm{CH})$ & $22.3\left(\mathrm{CH}_{2}\right)$ & $22.3\left(\mathrm{CH}_{2}\right)$ & $24.2\left(\mathrm{CH}_{2}\right)$ & $21.8\left(\mathrm{CH}_{2}\right)$ & $25.6\left(\mathrm{CH}_{2}\right)$ \\
\hline 7 & $127.0(\mathrm{CH})$ & $64.6(\mathrm{CH})$ & $125.2(\mathrm{CH})$ & $141.4(\mathrm{CH})$ & $127.0(\mathrm{CH})$ & $128.6(\mathrm{CH})$ & $127.6(\mathrm{CH})$ & $126.3(\mathrm{CH})$ & $126.5(\mathrm{CH})$ \\
\hline 10 & $25.1\left(\mathrm{CH}_{2}\right)$ & $23.6\left(\mathrm{CH}_{2}\right)$ & $24.3\left(\mathrm{CH}_{2}\right)$ & $23.5\left(\mathrm{CH}_{2}\right)$ & $24.2\left(\mathrm{CH}_{2}\right)$ & $23.8\left(\mathrm{CH}_{2}\right)$ & $24.3\left(\mathrm{CH}_{2}\right)$ & $24.5\left(\mathrm{CH}_{2}\right)$ & $24.8\left(\mathrm{CH}_{2}\right)$ \\
\hline 11 & $59.7(\mathrm{CH})$ & $59.0(\mathrm{CH})$ & $59.7(\mathrm{CH})$ & $126.7(\mathrm{CH})$ & $125.6(\mathrm{CH})$ & $126.9(\mathrm{CH})$ & $61.3(\mathrm{CH})$ & $59.2(\mathrm{CH})$ & $59.9(\mathrm{CH})$ \\
\hline 12 & $61.9(\mathrm{C})$ & $60.3(\mathrm{C})$ & $61.3(\mathrm{C})$ & $132.8(\mathrm{C})$ & $131.9(\mathrm{C})$ & $136.1(\mathrm{C})$ & $64.7(\mathrm{C})$ & $60.4(\mathrm{C})$ & $62.9(\mathrm{C})$ \\
\hline 13 & $72.8(\mathrm{CH})$ & $71.9(\mathrm{CH})$ & $71.6(\mathrm{CH})$ & $37.3\left(\mathrm{CH}_{2}\right)$ & $44.1\left(\mathrm{CH}_{2}\right)$ & $36.1\left(\mathrm{CH}_{2}\right)$ & $71.6(\mathrm{CH})$ & $72.7(\mathrm{CH})$ & $75.2(\mathrm{CH})$ \\
\hline 14 & $85.8(\mathrm{CH})$ & $85.0(\mathrm{CH})$ & $115.6(\mathrm{CH})$ & $122.0(\mathrm{CH})$ & $70.6(\mathrm{CH})$ & $29.9\left(\mathrm{CH}_{2}\right)$ & $122.9(\mathrm{CH})$ & $84.9(\mathrm{CH})$ & $68.1(\mathrm{CH})$ \\
\hline 15 & $26.6(\mathrm{CH})$ & $25.7(\mathrm{CH})$ & $27.6(\mathrm{CH})$ & $31.6(\mathrm{CH})$ & $27.8(\mathrm{CH})$ & $75.1(\mathrm{C})$ & $32.1(\mathrm{CH})$ & $25.7(\mathrm{CH})$ & $28.2(\mathrm{CH})$ \\
\hline \multirow[t]{2}{*}{ OAC } & & $169.9(\mathrm{C})$ & $170.7(\mathrm{C})$ & & & & & $169.9(\mathrm{C})$ & \\
\hline & & $21.0\left(\mathrm{CH}_{3}\right)$ & $21.1\left(\mathrm{CH}_{3}\right)$ & & & & & $20.6\left(\mathrm{CH}_{3}\right)$ & \\
\hline
\end{tabular}

Spectra recorded in ${ }^{a} \mathrm{C}_{6} \mathrm{D}_{6}$ at $100 \mathrm{MHz} ;{ }^{b} \mathrm{CDCl}_{3}$ at $125 \mathrm{MHz}$; and ${ }^{c} \mathrm{CDCl}_{3}$ at $100 \mathrm{MHz}$ at $2{ }^{\circ} \mathrm{C}^{d}$ Attached protons were determined by distortionless enhancement by polarization transfer (DEPT) experiments. Values are presented as ppm downfield from tetramethylsilane (TMS).

Table 2. ${ }^{1} \mathrm{H}$ NMR spectral data for compounds 1-5.

\begin{tabular}{|c|c|c|c|c|c|}
\hline$\#$ & $1^{a}$ & $2^{b}$ & $3^{c}$ & $4^{a}$ & $5^{c}$ \\
\hline 2 & 5.59 br s & 5.65 br s & $5.70 \mathrm{~d}(10.0)$ & $6.19 \mathrm{~d}(16.4)$ & $5.41 \mathrm{~d}(7.6)$ \\
\hline 3 & $4.61 \mathrm{~d}(4.8)^{d}$ & $4.78 \mathrm{~d}(5.0)$ & $5.25 \mathrm{~d}(10.0)$ & $5.83 \mathrm{~d}(16.4)$ & $4.34 \mathrm{~d}(7.6)$ \\
\hline 5 & $1.48 \mathrm{~m} ; 1.85, \mathrm{~m}$ & $1.82 \mathrm{~m} ; 1.92 \mathrm{~m}$ & $2.10 \mathrm{~m} ; 2.24 \mathrm{~m}$ & $2.312 \mathrm{H}, \mathrm{d}(6.8)$ & $1.55 \mathrm{~m} ; 1.86 \mathrm{~m}$ \\
\hline 6 & $2.02 \mathrm{~m} ; 2.15, \mathrm{~m}$ & $1.59 \mathrm{~m} ; 1.86 \mathrm{~m}$ & $2.10 \mathrm{~m} ; 2.27 \mathrm{~m}$ & $5.56 \mathrm{dd}(15.6,6.8)$ & $2.11 \mathrm{~m} ; 2.34 \mathrm{~m}$ \\
\hline 7 & $5.38 \mathrm{dd}(5.2,5.2)$ & $3.07 \mathrm{dd}(6.0,2.5)$ & 4.83 br d (6.0) & $5.52 \mathrm{~d}(15.6)$ & $4.99 \mathrm{dd}(6.0,6.0)$ \\
\hline 9 & $2.04 \mathrm{~m} ; 2.09 \mathrm{~m}$ & $2.10 \mathrm{~m} ; 1.39 \mathrm{~m}$ & $2.16 \mathrm{~m} ; 2.20 \mathrm{~m}$ & $1.58 \mathrm{~m} ; 1.67 \mathrm{~m}$ & $1.98 \mathrm{~m} ; 2.15 \mathrm{~m}$ \\
\hline 10 & $1.76 \mathrm{~m} ; 1.83 \mathrm{~m}$ & $1.54 \mathrm{~m} ; 1.95 \mathrm{~m}$ & $1.61 \mathrm{~m} ; 1.86 \mathrm{~m}$ & $2.01 \mathrm{~m} ; 2.37 \mathrm{~m}$ & $2.14 \mathrm{~m} ; 2.18 \mathrm{~m}$ \\
\hline 11 & 3.15 dd $(6.4,2.0)$ & $2.98 \mathrm{~d}(7.5)$ & $2.47 \mathrm{dd}(7.2,2.0)$ & $5.11 \mathrm{dd}(7.2,7.2)$ & $4.93 \mathrm{dd}(6.8,6.0)$ \\
\hline 13 & 3.58 br s & $5.21 \mathrm{~s}$ & $5.52 \mathrm{~d}(10.4)$ & $2.712 \mathrm{H}, \mathrm{d}(8.0)$ & $2.27 \mathrm{~m} ; 2.37 \mathrm{~m}$ \\
\hline 14 & 4.78 br d (4.8) & $5.05 \mathrm{~d}(5.0)$ & $5.03 \mathrm{~d}(10.4)$ & $5.48 \mathrm{dd}(8.0,5.6)$ & $4.78 \mathrm{dd}(5.6,5.6)$ \\
\hline 15 & 2.25 sept $(6.8)$ & $2.17 \mathrm{~m}$ & 2.78 sept $(6.8)$ & 2.53 sept $(6.8)$ & $2.48 \mathrm{~m}$ \\
\hline 16 & $0.943 \mathrm{H}, \mathrm{d}(6.8)$ & $1.053 \mathrm{H}, \mathrm{d}(6.5)$ & $1.053 \mathrm{H}, \mathrm{d}(6.8)$ & $1.093 \mathrm{H}, \mathrm{d}(6.8)$ & $1.063 \mathrm{H}, \mathrm{d}(6.8)$ \\
\hline 17 & $1.123 \mathrm{H}, \mathrm{d}(6.8)$ & $1.103 \mathrm{H}, \mathrm{d}(6.5)$ & $1.093 \mathrm{H}, \mathrm{d}(6.8)$ & $1.103 \mathrm{H}, \mathrm{d}(6.8)$ & $1.123 \mathrm{H}, \mathrm{d}(6.8)$ \\
\hline 18 & $0.983 \mathrm{H}, \mathrm{s}$ & $1.053 \mathrm{H}, \mathrm{s}$ & $1.803 \mathrm{H}, \mathrm{s}$ & $1.273 \mathrm{H}, \mathrm{s}$ & $1.143 \mathrm{H}, \mathrm{s}$ \\
\hline 19 & $1.483 \mathrm{H}, \mathrm{s}$ & $1.243 \mathrm{H}, \mathrm{s}$ & $1.553 \mathrm{H}, \mathrm{s}$ & $1.163 \mathrm{H}, \mathrm{s}$ & $1.553 \mathrm{H}, \mathrm{s}$ \\
\hline 20 & $1.183 \mathrm{H}, \mathrm{s}$ & $1.423 \mathrm{H}, \mathrm{s}$ & $1.223 \mathrm{H}, \mathrm{s}$ & $1.603 \mathrm{H}, \mathrm{s}$ & $1.683 \mathrm{H}, \mathrm{s}$ \\
\hline OAc & & $1.913 \mathrm{H}, \mathrm{s}$ & $2.103 \mathrm{H}, \mathrm{s}$ & & \\
\hline
\end{tabular}

Spectra recorded in ${ }^{a} \mathrm{C}_{6} \mathrm{D}_{6}$, at $400 \mathrm{MHz} ;{ }^{b} \mathrm{CDCl}_{3}$ at $500 \mathrm{MHz}$; and ${ }^{c} \mathrm{CDCl}_{3}$ at $400 \mathrm{MHz}$ at $25{ }^{\circ} \mathrm{C} ;{ }^{d} J$ values $(\mathrm{Hz})$ in parentheses. 


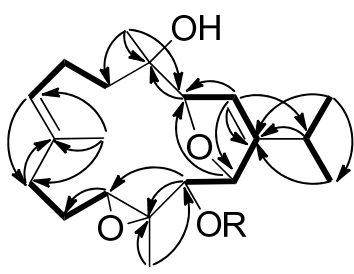

1: $\mathrm{R}=\mathrm{H}$

8: $R=A C$

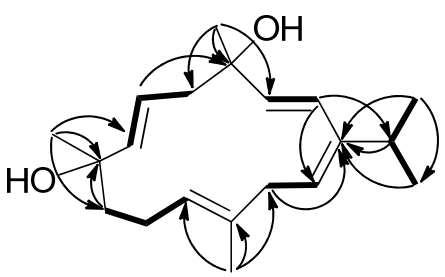

4

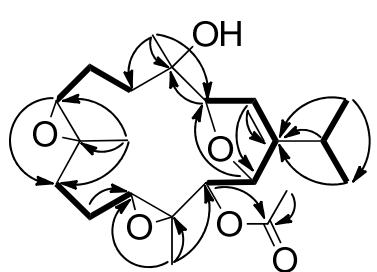

2

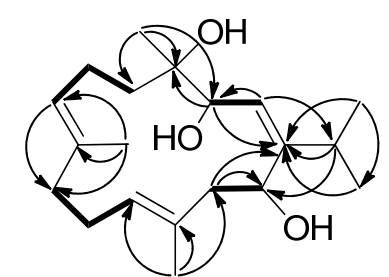

5

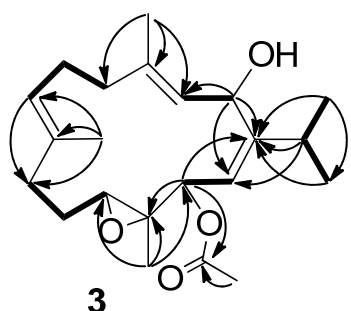

3

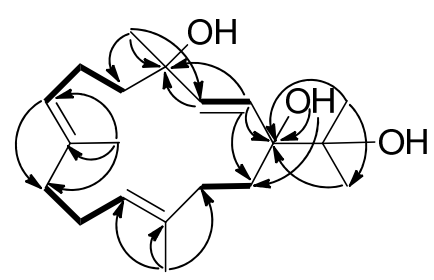

6

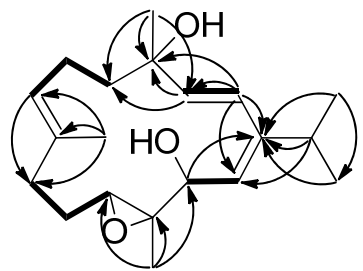

7

Figure 2. Correlation spectroscopy (COSY) and heteronuclear multiple bond correlation (HMBC) correlations in $\mathbf{1 - 8}$.

The relative configuration of $\mathbf{1}$ was determined by the analysis of nuclear Overhauser effect (NOE) correlations in a nuclear Overhauser enhancement spectroscopy (NOESY) experiment and with the assistance of ${ }^{5} \mathrm{~J}_{\mathrm{H}, \mathrm{H}}$ coupling constants, in addition to molecular modeling using molecular mechanical parameters (MM2 force field) calculations (Figure 3). The high magnitude of the long-range coupling constant of $\mathrm{H}-3$ and $\mathrm{H}-14(\mathrm{~J}=4.8 \mathrm{~Hz})$ of the 2,5-dihydrofuran ring in 1 suggested the trans orientation of protons at C-3/C-14 [19]. Accordingly, no NOE correlation was detected between $\mathrm{H}-3$ and $\mathrm{H}-14$. From the NOESY spectrum of 1 , it was found that $\mathrm{H}_{3}-18$ showed NOE interaction with $\mathrm{H}-14$, and $\mathrm{H}-14$ with $\mathrm{H}-13$ and $\mathrm{H}_{3}-20$; therefore, due to the $\beta$-orientation of $\mathrm{H}_{3}-18, \mathrm{H}-13$ and $\mathrm{H}-14$ should also be positioned on the $\beta$-face. Furthermore, H-3 exhibited NOE correlation with the olefinic $\mathrm{H}-7$, as did $\mathrm{H}-7$ with $\mathrm{H}-11$, while $\mathrm{H}-11$ did not show NOE interaction with $\mathrm{H}_{3}-20$, revealing that $\mathrm{H}-3$ and $\mathrm{H}-11$ should be positioned on the $\alpha$-face. Moreover, the NOE interactions exhibited for the olefinic $\mathrm{H}-2$ with $\mathrm{H}_{3}-17$ and for $\mathrm{H}_{3}-19$ with $\mathrm{H}-9$, but not with $\mathrm{H}-7$, enabled the assignment of $Z$ and $E$ geometries of the double bonds at $C-1 / C-2$ and $C-7 / C-8$, respectively. As a result, the $\left(3 R^{*}, 4 S^{*}, 11 S^{*}, 12 R^{*}, 13 S^{*}, 14 R^{*}\right)$-configuration of 1 was established.

After isolation and chemical identification of $\mathbf{1}$, related compound klyflaccicembranol $\mathrm{H}(8)$ was isolated from the less polar fraction of the same extract of the organism. Compound 8 possessed the molecular formula $\mathrm{C}_{22} \mathrm{H}_{34} \mathrm{O}_{5}$, as indicated by the HRESIMS $\left(\mathrm{m} / \mathrm{z} 378.2404\right.$ [M] $\left.{ }^{+}\right)$and NMR data (Tables 1 and 3). IR absorptions at $v_{\max } 3310$ and $1730 \mathrm{~cm}^{-1}$ and electron ionization mass spectroscopy EIMS ion peaks at $m / z 318[\mathrm{M}-\mathrm{AcOH}]^{+}$and $m / z 300\left[\mathrm{M}-\mathrm{AcOH}-\mathrm{H}_{2} \mathrm{O}\right]^{+}$revealed the presence of hydroxy and acetoxy functionalities in the molecule of 8. On comparison of spectroscopic data, the NMR spectrum of $\mathbf{8}$ was found to be very similar to that of $\mathbf{1}$ (Tables 1-3), with the exception of the presence of signals of an additional methyl and an ester carbonyl carbon of an acetoxy group 
at $\delta_{\mathrm{C}} 169.9, \mathrm{C}$ and 20.6, $\mathrm{CH}_{3}$; and $\delta_{\mathrm{H}} 2.06,3 \mathrm{H}$, s. These were associated with a downfield shift displayed by $\mathrm{H}-13$ in $8\left(\delta_{\mathrm{H}} 5.16, \mathrm{~d}, J=2.0 \mathrm{~Hz}\right)$ relative to that of $1\left(\delta_{\mathrm{H}} 3.58, \mathrm{br}\right.$ s). Therefore, 8 was suggested to be the 13-acetylated derivative of 1 , as proven by complete $2 \mathrm{D}$ NMR correlations analyses (Figure 2). Moreover, compound 8, measured in $\mathrm{CDCl}_{3}$, showed the same $\mathrm{NOE}$ correlations that had been observed in the NOESY spectrum of $\mathbf{1}$, indicating the same relative configuration. Furthermore, hydrolysis of $\mathbf{8}$ yielded $\mathbf{1}$. To clarify the absolute configuration at $\mathrm{C}-\mathbf{1 3}$ in $\mathbf{1}$ (and hence also in 8), a modified Mosher's method [20,21] was employed to prepare (S)- and (R)- $\alpha$-methoxy- $\alpha$ (trifluoromethyl)phenylacetic (MTPA) esters of $\mathbf{1}$ (1a and $\mathbf{1} \mathbf{b}$, respectively) using the corresponding (-)and (+)-MTPA-chloride, respectively. Calculation of $\Delta \delta$ values $\left(\delta_{\mathrm{H}} S-\delta_{\mathrm{H}} R\right)$ for the protons adjacent to C-13 led to the assignment of the $S$ configuration at C-13 in $\mathbf{1}$, and consequently therefore in 8 (Figure 4). On the basis of the above findings and detailed NOESY correlations analyses (Figure 3), compound 1 was identified as $(3 R, 4 S, 11 S, 12 R, 13 S, 14 R, 1 Z, 7 E)$-4,13-dihydroxy-3,14:11,12-bisepoxy-cembra-1,7-diene. Compound 8 (klyflaccicembranol H) was thus subsequently characterized as the $\mathrm{C}-13$ acetyl derivative of 1 .

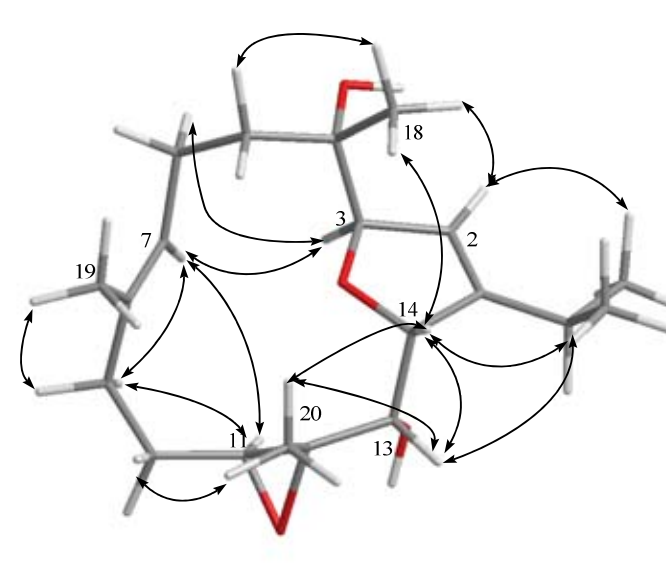

$\mathbf{1}$ and $\mathbf{8}(13-\mathrm{OAc})$

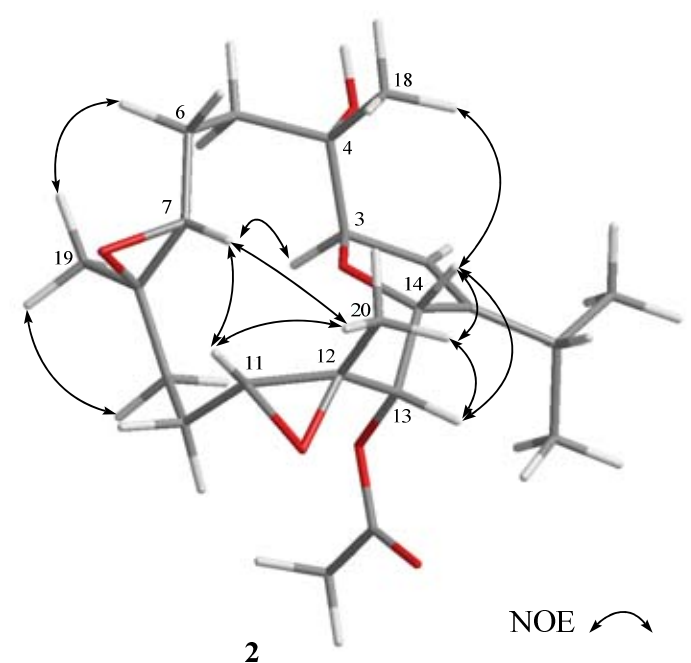

2

Figure 3. Key nuclear Overhauser effect (NOE) correlations of 1, 8 and 2. 
Table 3. ${ }^{1} \mathrm{H}$ NMR spectral data for compounds 6-9.

\begin{tabular}{|c|c|c|c|c|}
\hline$\#$ & $6^{a}$ & $7^{b}$ & $8^{b}$ & $9^{c}$ \\
\hline 2 & $5.61 \mathrm{~d}(16.0)^{d}$ & $6.24 \mathrm{~d}(16.0)$ & 5.60 br s & $6.25 \mathrm{~d}(11.2)$ \\
\hline 3 & $6.10 \mathrm{~d}(16.0)$ & $5.75 \mathrm{~d}(16.0)$ & $4.57 \mathrm{~d}(5.2)$ & $5.85 \mathrm{~d}(11.2)$ \\
\hline 5 & $1.51 \mathrm{~m} ; 2.01 \mathrm{~m}$ & $2.10 \mathrm{~m} ; 2.24 \mathrm{~m}$ & $1.63 \mathrm{~m} ; 1.89 \mathrm{~m}$ & $2.002 \mathrm{H}, \mathrm{m}$ \\
\hline 6 & $2.22 \mathrm{~m} ; 2.39 \mathrm{~m}$ & $2.10 \mathrm{~m} ; 2.27 \mathrm{~m}$ & $2.16 \mathrm{~m} ; 2.18 \mathrm{~m}$ & $1.97 \mathrm{~m}, 2.06 \mathrm{~m}$ \\
\hline 7 & $5.34 \mathrm{dd}(7.5,7.5)$ & $5.03 \mathrm{dd}(6.0,6.0)$ & $5.36 \mathrm{dd}(5.5,5.5)$ & $5.03 \mathrm{dd}(6.0,6.0)$ \\
\hline 9 & $1.95 \mathrm{~m} ; 2.20 \mathrm{~m}$ & $2.16 \mathrm{~m} ; 2.20 \mathrm{~m}$ & $2.04 \mathrm{~m} ; 2.09 \mathrm{~m}$ & $1.95 \mathrm{~m}, 2.11 \mathrm{~m}$ \\
\hline 10 & $2.07 \mathrm{~m} ; 2.24 \mathrm{~m}$ & $1.61 \mathrm{~m} ; 1.86 \mathrm{~m}$ & $1.76 \mathrm{~m} ; 1.83 \mathrm{~m}$ & $1.432 \mathrm{H}, \mathrm{m}$ \\
\hline 11 & 5.19 br d (9.0) & $2.67 \mathrm{~m}$ & $2.89 \mathrm{dd}(6.0,3.6)$ & $3.08 \mathrm{dd}(6.0,6.0)$ \\
\hline 13 & $2.13 \mathrm{~m} ; 2.19 \mathrm{~m}$ & $4.59 \mathrm{dd}(8.0,8.0)$ & $5.16 \mathrm{~d}(2.0)$ & $3.72 \mathrm{~d}(6.0)$ \\
\hline 14 & $1.63 \mathrm{~m} ; 2.11 \mathrm{~m}$ & $5.10 \mathrm{~d}(8.0)$ & $5.00 \mathrm{dd}(5.2,2.0)$ & $4.60 \mathrm{~d}(6.0)$ \\
\hline 15 & & $2.52 \mathrm{~m}$ & $2.13 \mathrm{~m}$ & $2.76 \mathrm{~m}$ \\
\hline 16 & $1.213 \mathrm{H}, \mathrm{s}$ & $1.043 \mathrm{H}, \mathrm{d}(6.8)$ & $1.033 \mathrm{H}, \mathrm{d}(6.8)$ & $1.06 \mathrm{~d}(6.8)$ \\
\hline 17 & $1.133 \mathrm{H}, \mathrm{s}$ & $1.073 \mathrm{H}, \mathrm{d}(6.8)$ & $1.083 \mathrm{H}, \mathrm{d}(6.8)$ & $1.28 \mathrm{~d}(6.8)$ \\
\hline 18 & $1.403 \mathrm{H}, \mathrm{s}$ & $1.353 \mathrm{H}, \mathrm{s}$ & $1.003 \mathrm{H}, \mathrm{s}$ & $1.593 \mathrm{H}, \mathrm{s}$ \\
\hline 19 & $1.623 \mathrm{H}, \mathrm{s}$ & $1.603 \mathrm{H}, \mathrm{s}$ & $1.593 \mathrm{H}, \mathrm{s}$ & $1.323 \mathrm{H}, \mathrm{s}$ \\
\hline 20 & $1.673 \mathrm{H}, \mathrm{s}$ & $1.423 \mathrm{H}, \mathrm{s}$ & $1.393 \mathrm{H}, \mathrm{s}$ & $1.343 \mathrm{H}, \mathrm{s}$ \\
\hline $15-\mathrm{OH}$ & $2.60 \mathrm{~s}$ & & & \\
\hline $13-\mathrm{OH}$ & & $1.74 \mathrm{~d}(8.0)$ & & \\
\hline OAc & & & $2.063 \mathrm{H}, \mathrm{s}$ & \\
\hline
\end{tabular}

Spectra recorded in ${ }^{a} \mathrm{CDCl}_{3}$ at $500 \mathrm{MHz} ;{ }^{b} \mathrm{CDCl}_{3}$ at $400 \mathrm{MHz}$; and ${ }^{c} \mathrm{C}_{6} \mathrm{D}_{6}$ at $400 \mathrm{MHz}$ at $25^{\circ} \mathrm{C}^{d} \mathrm{~J}$ values $(\mathrm{Hz})$ in parentheses.

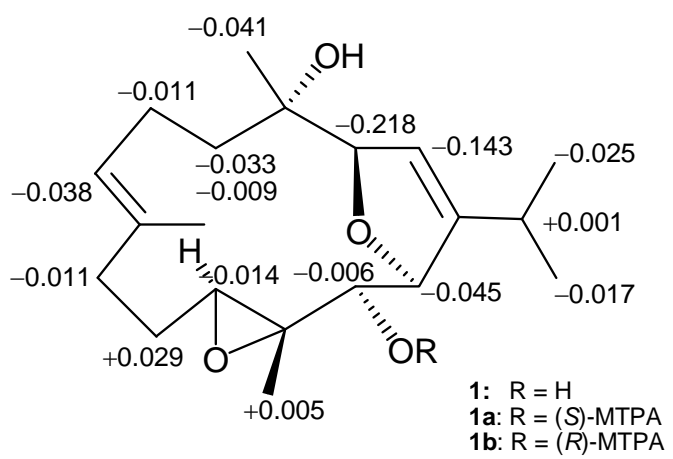

Figure 4. ${ }^{1} \mathrm{H}$ NMR chemical shift differences $\Delta \delta(\delta S-\delta R)$ in ppm for the $\alpha$-methoxy- $\alpha$-(trifluoromethyl) phenylacetic (MTPA) esters of $\mathbf{1}$.

Klyflaccicembranol B (2) was also isolated as a colorless oil. The sodium adduct ion peak $[\mathrm{M}+\mathrm{Na}]^{+}$ appearing at $m / z 417.2250$ in the HRESIMS was appropriate for the molecular formula $\mathrm{C}_{22} \mathrm{H}_{34} \mathrm{O}_{6}$ with six unsaturations. The IR absorption bands at $v_{\max } 3443$ and $1746 \mathrm{~cm}^{-1}$ indicated hydroxy and ester functionalities in the molecule. The NMR signals $\left(\delta_{\mathrm{C}} 169.9, \mathrm{C}\right.$ and $21.0, \mathrm{CH}_{3} ; \delta_{\mathrm{H}} 1.91,3 \mathrm{H}$, s) showed the ester functionality to be an acetoxy group. A trisubstituted-2,5-dihydrofuran moiety $\left(\delta_{\mathrm{C}} 147.7, \mathrm{C}\right.$; 121.2, $\mathrm{CH} ; 91.1, \mathrm{CH}$ and $85.0, \mathrm{CH} ; \delta_{\mathrm{H}} 5.65, \mathrm{br} \mathrm{s} ; 5.05, \mathrm{~d}, J=5.0 \mathrm{~Hz}$ and $4.78, \mathrm{~d}, J=5.0 \mathrm{~Hz}$ ) was also deduced, as in case of $\mathbf{1}$ and $\mathbf{8}$. However, the ${ }^{13} \mathrm{C}$ NMR spectral comparison of compound $\mathbf{2}$ with $\mathbf{8}$ in the regions of $\delta_{C} 125-140$ and 58-65 ppm indicated that 2 had an additional trisubstituted epoxide, instead of the 7,8-trisubstiututed double bond in 8 . The gross structure of 2 was thus established by analysis of COSY and HMBC correlations (Figure 2). The relative configuration of $\mathbf{2}$ was determined by analysis of NOE correlations, as shown in Figure 3. The NOE interactions observed for $\mathrm{H}_{3}-19$ $\left(\delta_{\mathrm{H}} 1.24, \mathrm{~s}\right)$ with $\mathrm{H}-6\left(\delta_{\mathrm{H}} 1.59, \mathrm{~m}\right), \mathrm{H}-7\left(\delta_{\mathrm{H}} 3.07, \mathrm{dd}, J=6.0,2.5 \mathrm{~Hz}\right)$ with $\mathrm{H}-3$, and H-11 $\left(\delta_{\mathrm{H}} 2.98, \mathrm{~d}\right.$, $J=7.5 \mathrm{~Hz})$ with $\mathrm{H}_{3}-20\left(\delta_{\mathrm{H}} 1.42, \mathrm{~s}\right)$, indicated the trans and cis geometries of the trisubstituted 7,8- and 11,12-epoxides, respectively. As H-3 exhibited a NOE correlation with H-7, H-7 and $\mathrm{H}_{3}-19$ were thus $\alpha$ - and $\beta$-oriented, respectively. Moreover, the NOE correlations observed for H-14 with both $\mathrm{H}_{3}-20$ and $\mathrm{H}-13$ disclosed the $\alpha$-orientation of the acetyl group at $\mathrm{C}-13$ and the $\beta$-orientation of the 
methyl group at $C-12$, and hence the $\beta$-oriented epoxide proton at $C-11$. On the basis of the above findings and the absolute configuration of biogenetically-related $\mathbf{1}$, compound $\mathbf{2}$ was thus determined as $(3 R, 4 S, 7 R, 8 R, 11 R, 12 R, 13 S, 14 R, 1 Z)-7,8: 11,12: 3,14$-triepoxy-4-hydroxy-13- acetoxycembra-1-ene.

New metabolite 3 was found to have the molecular formula $\mathrm{C}_{22} \mathrm{H}_{34} \mathrm{O}_{4}$, as deduced from the HRESIMS $\left(m / z 385.2354[\mathrm{M}+\mathrm{Na}]^{+}\right)$and NMR data (Tables 1 and 2), implying six degrees of unsaturation. As in the cases of 2 and $\mathbf{8}$, the IR absorptions at 1731 and $3450 \mathrm{~cm}^{-1}$ further indicated the presence of an ester moiety and a hydroxy group. The NMR data (Tables 1 and 2) of an acetoxy group $\left(\delta_{\mathrm{C}} 170.7, \mathrm{C} ; 21.1, \mathrm{CH}_{3} ; \delta_{\mathrm{H}} 2.10,3 \mathrm{H}, \mathrm{s}\right)$, a trisubstituted epoxide $\left(\delta_{\mathrm{C}} 61.3, \mathrm{C}\right.$ and $\left.59.7, \mathrm{CH}\right)$ and three trisubstituted olefins $\left(\delta_{C} 155.9,137.6,133.2\right.$, each $C$, and 126.3, 125.2, 115.6, each $\left.\mathrm{CH}\right)$ established five degrees of unsaturation in the molecule. By comparison of NMR spectroscopic data with those of gibberosene D (10) isolated from the soft coral S. gibberosa [16], compound 3 was suggested to be a regioisomer of $\mathbf{1 0}$. Interpretation of 2D NMR correlations (Figure 2) indicated a secondary hydroxy group at C-2 and a trisubstituted double bond at C-3/C-4 in 3 instead of the disubstituted double bond and the tertiary hydroxy group at C-2/C-3 and C-4, respectively, in 10. Detailed COSY and HMBC correlations (Figure 2) further determined the C-7/C-8, C-1/C-14, C-11/C-12, and C-13 positions for the two other olefins, the epoxide, and the acetoxy group in the structure of 3, respectively, as were identified in $\mathbf{1 0}$ (Figure 1). Thus, the gross structure of 3 was established as 13-acetoxy-11,12-epoxy-2-hydroxycembra-3,7,14-triene. The NOE interaction of H-13 with $\mathrm{H}-2$ enabled assignment of their syn positions, and hence the $\alpha$-orientation of the hydroxy group at $\mathrm{C}-2$, based on the previously defined $S$ configuration at $\mathrm{C}-13$ (as in $\mathbf{1}$ and $\mathbf{8}$ ). The NOE interactions of $\mathrm{H}-14$ with $\mathrm{H}_{3}-20\left(\delta_{\mathrm{H}} 1.22,3 \mathrm{H}, \mathrm{s}\right)$ and $\mathrm{H}-13$ with $\mathrm{H}-11\left(\delta_{\mathrm{H}} 2.47, \mathrm{dd}, J=7.2,2.0 \mathrm{~Hz}\right)$ indicated the trans geometry of the 11,12-epoxide, and, consequently, the $11 S$ and $12 R$ configurations. Furthermore, other NOE interactions of $\mathrm{H}-2$ with $\mathrm{H}_{3}-18\left(\delta_{\mathrm{H}} 1.80,3 \mathrm{H}, \mathrm{s}\right), \mathrm{H}-3$ with $\mathrm{H}-7\left(\delta_{\mathrm{H}} 4.83, \mathrm{br} \mathrm{d}, J=6.0 \mathrm{~Hz}\right)$, and $\mathrm{H}_{3}-19\left(\delta_{\mathrm{H}} 1.55,3 \mathrm{H}, \mathrm{s}\right)$ with $\mathrm{H}-6\left(\delta_{\mathrm{H}} 2.27, \mathrm{~m}\right)$ established the $E$ geometries of the C-3/C-4 and $\mathrm{C}-7 / \mathrm{C}-8$ double bonds. The $\mathrm{Z}$ geometry of the double bond at C-14/C-1 in 3 was proven by the NOE correlation (Figure 5) of H-14 with the isopropyl methyls at $\mathrm{C}-15\left(\delta_{\mathrm{H}} 1.05\right.$ and 1.09 , each $3 \mathrm{H}$, $\mathrm{d}, J=6.8 \mathrm{~Hz}$ ). The above observations thus established the structure of klyflaccicembranol C (3) as (2S,11S,12R,13S,3E,7E,14Z)-13-acetoxy-11,12-epoxy-2-hydroxycembra-3,7,14-triene.

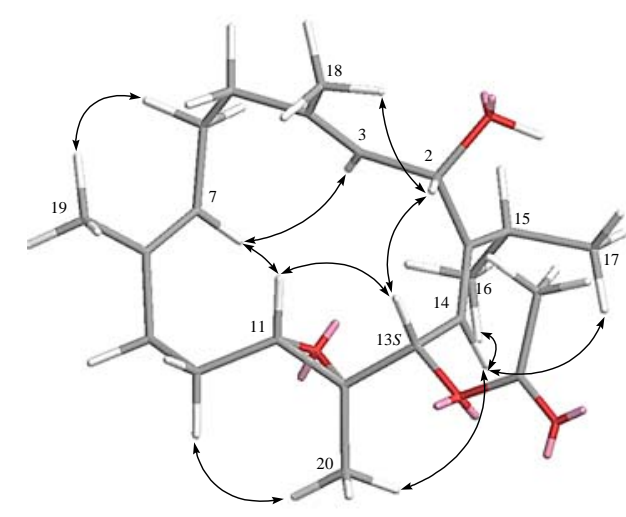

3

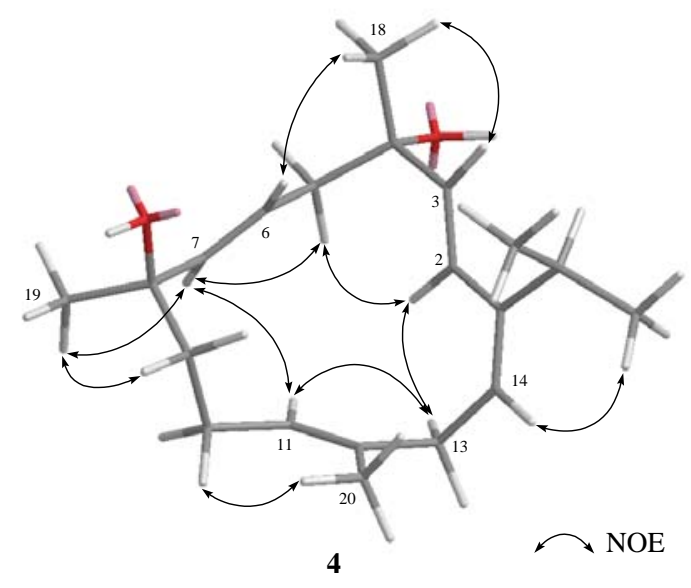

4

Figure 5. Key NOE correlations of 3 and 4 .

New metabolite klyflaccicembranol D (4) was isolated as a pale oil. A pseudomolecular ion peak $[\mathrm{M}+\mathrm{Na}]^{+}$at $m / z 327.2200$ in the HRESIMS data was observed, corresponding to the molecular formula $\mathrm{C}_{20} \mathrm{H}_{32} \mathrm{O}_{2}$ and five degrees of unsaturation. The IR absorption at $v_{\max } 3419 \mathrm{~cm}^{-1}$ and two $s p^{3}$ oxycarbon signals appearing at $\delta_{C} 72.9$ and 72.5 indicated the hydroxyl-bearing characteristic of the compound. Two trisubstituted double bonds were also identified from the NMR signals at $\delta_{\mathrm{C}} 146.3, \mathrm{C} ; 132.8, \mathrm{C} ; 126.7, \mathrm{CH} ; 122.0, \mathrm{CH} ; \delta_{\mathrm{H}} 5.48(1 \mathrm{H}, \mathrm{dd}, J=8.0,5.6 \mathrm{~Hz})$, and $5.11(1 \mathrm{H}, \mathrm{dd}$, 
$J=7.2,7.2 \mathrm{~Hz}$ ). Analysis of COSY correlations of 4 established five consecutive proton sequences, including those of the isopropyl group (Figure 2). Careful study of the HMBC spectrum of 4 further established the connectivities of the five proton sequences with the diagnostic nonprotonated carbons (C-1, C-4, C-8, and C-12), as illustrated in Figure 2. Thus, the two 1,2-disubstuituted and the two trisubstituted double bonds were localized at C-2/C-3, C-6/C-7, C-11/C-12, and C-14/C-1, respectively, whereas the hydroxy groups were positioned at C-4 and C-8. Thus, the planar structure of 4 was established as 4,8-dihydroxycembra-2,6,11,14-tetraene. The large coupling constants of $J_{2,3}(16.4 \mathrm{~Hz})$ and $J_{6,7}(15.6 \mathrm{~Hz})$ reflected the $E$ geometries of the two disubstituted double bonds at C-2/C-3 and C-6/C-7. Moreover, the NOE correlations (Figure 5) found for $\mathrm{H}_{3}-20(1.60,3 \mathrm{H}, \mathrm{s})$ with one proton of $\mathrm{H}_{2}-10\left(\delta_{\mathrm{H}} 2.37, \mathrm{~m}\right)$, but not with $\mathrm{H}-11$, and for $\mathrm{H}-14$ with the protons of the two methyls at $\mathrm{C}-15$, indicated the $E$ and $Z$ geometries of the double bonds at C-11/C-12 and C-1/C-14, respectively. On the basis of the previously defined $\alpha$-orientation of 4-OH in biogenetically-related compounds 1,2 , and 8 , and the NOE interactions of the $\beta$-oriented $\mathrm{H}_{3}-18$ $\left(\delta_{\mathrm{H}} 1.27,3 \mathrm{H}, \mathrm{s}\right)$ with the olefinic $\mathrm{H}-6$ and the trans downward-oriented $\mathrm{H}-7$ with $\mathrm{H}_{3}-19\left(\delta_{\mathrm{H}} 1.16,3 \mathrm{H}\right.$, $\mathrm{s})$, the $\beta$-orientation of the hydroxy group at $\mathrm{C}-8$ was proven. These findings, together with detailed analysis of other NOE correlations (Figure 4), indicated the structure of klyflaccicembranol D (4) to be (4S,8R,2E,6E,11E,14Z)-4,8-dihydroxycembra-2,6,11,14-tetraene.

Klyflaccicembranol E (5) was obtained as a colorless oil. It possessed the molecular formula $\mathrm{C}_{20} \mathrm{H}_{34} \mathrm{O}_{3}$ and four unsaturations, as concluded from the pseudomolecular ion peak $[\mathrm{M}+\mathrm{Na}]^{+}$at $\mathrm{m} / z$ 345.2404 in the HRESIMS. The presence of hydroxy groups in $\mathbf{5}$ was demonstrated by an IR absorption band at $\gamma_{\max } 3408 \mathrm{~cm}^{-1}$ and ${ }^{13} \mathrm{C}$ NMR signals at $\delta_{\mathrm{C}} 75.2(\mathrm{C}), 70.7(\mathrm{CH})$, and $70.6(\mathrm{CH})$. The NMR spectroscopic data comparison of 5 with semisynthetic product 11 (Figure 6), obtained by chromic acid oxidation of sarcophytol A [22], suggested that $5\left(\mathrm{C}_{20} \mathrm{H}_{34} \mathrm{O}_{3}\right)$ was the hydrated derivative of $11\left(\mathrm{C}_{20} \mathrm{H}_{32} \mathrm{O}_{2}\right)$. Therefore, the 3,14-dihydroxy compound 5, relative to the 3,14-epoxy compound 11, exhibited significant upfield $\left(\Delta \delta_{C}-8.5,-6.5,-13.9 \mathrm{ppm}\right)$ and downfield $\left(\Delta \delta_{C}+3.6 \mathrm{ppm}\right)$ shifts at $C-2$, C-3, C-14, and C-1, respectively. Furthermore, extensive interpretation of 2D NMR correlations further established the gross structure of compound 5 to be 3,4,14-trihydroxycembra-1(2),7,11-triene (Figure 2). The geometries of the double bonds and stereochemistries at C-3, C-4, and C-14 were determined by careful investigation of NOE correlations exhibited in the NOESY spectrum (Figure 7) in combination with molecular modelling. The NOE correlations of the olefinic $\mathrm{H}-2$ with protons of the isopropyl methyls $\left(\mathrm{H}_{3}-16\right.$ and $\left.\mathrm{H}_{3}-17\right)$ revealed the $\mathrm{Z}$ geometry of the double bond at $\mathrm{C}-1 / \mathrm{C}-2$. The chemical shift values of C-19 (15.1) and C-20 (17.1) reflected the $E$ geometries of the trisubstituted double bonds $\left(\delta_{\mathrm{C}}<20 \mathrm{ppm}\right)$ at C-7/C-8 and C-11/C-12 in the molecule of 5. Assuming an S-configuration at C-4 (as found in biogenetically-related metabolites 1, 2, and 8), the NOE interaction of $\mathrm{H}-2$ with $\mathrm{H}_{3}-18$, but not with $\mathrm{H}-3$, reflected the $R$-configuration at C-3. Consequently, the $S$-configuration was allocated for C-14, as H-14 exhibited strong NOE correlation with H-3. The above-mentioned findings, along with detailed analysis of other NOE correlations (Figure 7), identified klyflaccicembranol E (5) as $(3 R, 4 S, 14 S, 1 Z, 7 E, 11 E)-3,4,14$-trihydroxycembra-1,7,11-triene.

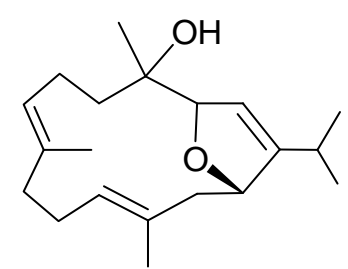

11

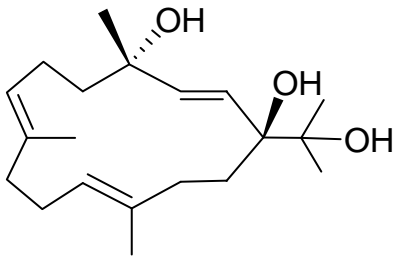

12

Figure 6. Structures of semisynthetic cembranoid (11) and crassumol A (12). 

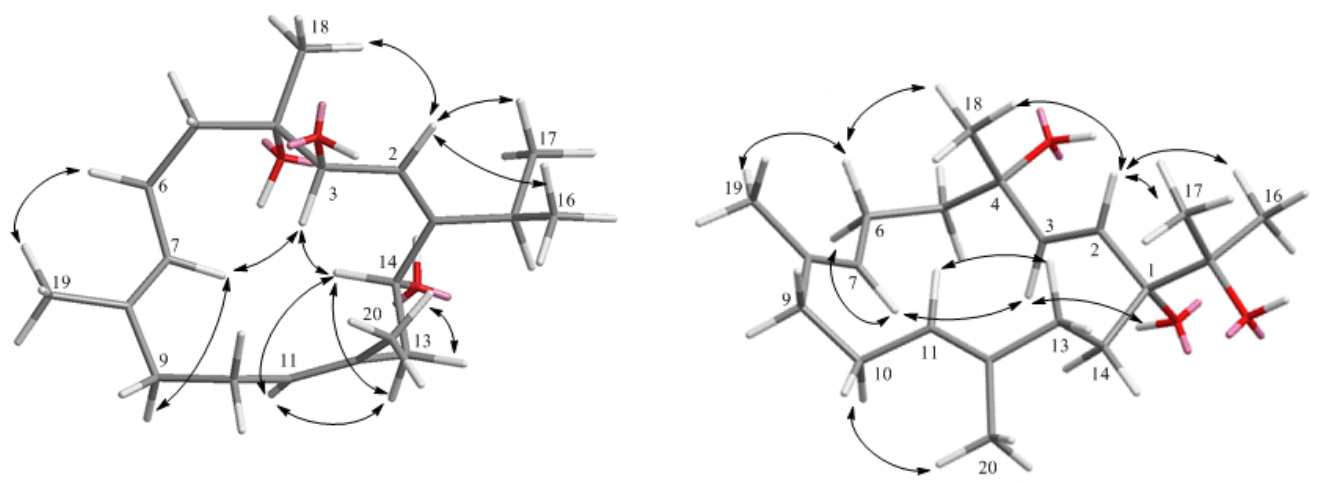

5

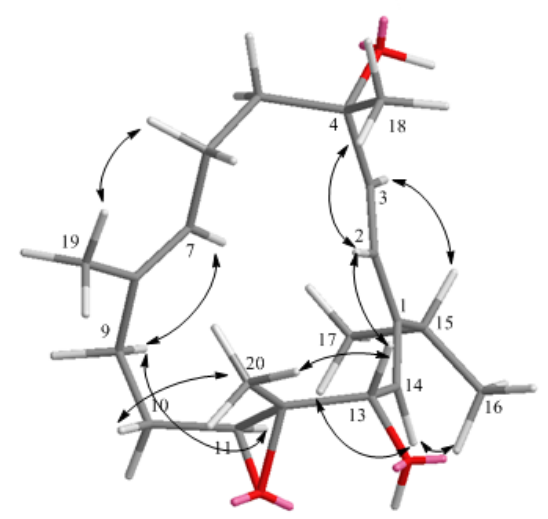

6

Figure 7. Key NOE correlations of 5-7.

Klyflaccicembranol F (6) displayed a pseudomolecular ion peak at $m / z, 345.2405\left([\mathrm{M}+\mathrm{Na}]^{+}\right)$in the HRESIMS, consistent with a molecular formula of $\mathrm{C}_{20} \mathrm{H}_{34} \mathrm{O}_{3}$ and four degrees of unsaturation. Its IR spectrum also showed a broad absorption band at $v_{\max } 3392 \mathrm{~cm}^{-1}$, representing a hydroxy group. This was further supported by NMR signals resonating at $\delta_{C} 80.9,75.1$, and 71.9 (each $C$ ) of tertiary hydroxyl-bearing carbons and a hydroxy proton at $\delta_{\mathrm{H}} 2.60(1 \mathrm{H}, \mathrm{s})$. Moreover, carbon signals appearing at $\delta_{\mathrm{C}} 129.2(\mathrm{C}-2, \mathrm{CH}), 138.0(\mathrm{C}-3, \mathrm{CH}), 128.6(\mathrm{C}-7, \mathrm{CH}), 132.7(\mathrm{C}-8, \mathrm{C}), 126.9$ (C-11, CH), and $136.1(\mathrm{C}-12, \mathrm{C})$ indicated the presence of one disubstituted double bond and two trisubstituted olefins in $\mathbf{6}$, respectively. The analysis of COSY correlations (Figure 2) of 6 indicated four consecutive proton sequences. The connection of four partial structures was subsequently resolved by the HMBC. Furthermore, long-range correlations observed from both $\mathrm{H}_{3}-16$ and $\mathrm{H}_{3}-17\left(\delta_{\mathrm{H}} 1.13\right.$ and 1.21, each $3 \mathrm{H}, \mathrm{s})$ to $\mathrm{C}-15\left(\delta_{\mathrm{C}} 75.1, \mathrm{C}\right)$ and $\mathrm{C}-1\left(\delta_{\mathrm{C}} 80.9, \mathrm{C}\right), 1-\mathrm{OH}\left(\delta_{\mathrm{H}} 2.60,1 \mathrm{H}, \mathrm{s}\right)$ to $\mathrm{C}-1$ and $\mathrm{C}-14$, and $\mathrm{H}-2\left(\delta_{\mathrm{H}} 5.61,1 \mathrm{H}, \mathrm{d}, J=16.0 \mathrm{~Hz}\right)$ to $\mathrm{C}-1$ and $\mathrm{C}-4\left(\delta_{\mathrm{C}} 71.9, \mathrm{C}\right)$, enabled localization of the hydroxy groups at C-15, C-1, and C-4, respectively. The planar structure of compound 6 was thus described as 1,4,15-trihydroxycembra-2,7,11-triene (Figure 2). Comparison of NMR data of 6 with the known cembranoid crassumol A (12) [23] revealed that 6 had similar ${ }^{1} \mathrm{H}$ and ${ }^{13} \mathrm{C}$ chemical shifts, except for the significant downfield shifts noticed at $\mathrm{C}-3, \mathrm{C}-4, \mathrm{C}-5\left(\Delta \delta_{\mathrm{C}}+1.1,+1.8\right.$, and +1.5 , respectively) and $\mathrm{H}-2\left(\Delta \delta_{\mathrm{H}}+0.18\right)$, and upfield shifts at $\mathrm{C}-2\left(\Delta \delta_{\mathrm{C}}-0.9 \mathrm{ppm}\right)$ and $\mathrm{H}-3\left(\Delta \delta_{\mathrm{H}}-0.18 \mathrm{ppm}\right)$, which suggested klyflaccicembranol F (6) to be the 1-epimer of 12 (Figure 6). Careful investigation of key NOE correlations (Figure 7) enabled us to prove the $\alpha$-orientation of 1-OH. In the NOESY spectrum of 6, $\mathrm{H}_{3}-18$ was found to exhibit correlation with $\mathrm{H}-2$, and $\mathrm{H}-2$ with both $\mathrm{H}_{3}-16$ and $\mathrm{H}_{3}-17$; therefore, assuming a $\beta$-orientation of $\mathrm{H}_{3}-18, \mathrm{H}-2$ and the isopropyl methyls should also be positioned on the $\beta$-face. Therefore, $1-\mathrm{OH}$ and $4-\mathrm{OH}$ should be $\alpha$-oriented. The chemical shift values of $\mathrm{C}-19\left(\delta_{C} 14.7\right)$ and C-20 $\left(\delta_{C} 14.8\right)$ reflected the $E$ geometries of the trisubstituted double bonds at C-7/C-8 and C-11/C-12 in the molecule of 6 . Moreover, it should be noted that the large $J_{H H}$ values for H-2 and H-3 $\left(\delta_{\mathrm{C}} 16.0 \mathrm{~Hz}\right)$ and the null NOE response reflected the trans positions of these two protons. On the basis of the above findings, metabolite 6 was determined to be $(1 R, 4 S, 2 E, 7 E, 11 E)-1,4,15$ - trihydroxycembra-2,7,11-triene. 
New metabolite 7 was also isolated as a colorless oil, with the molecular formula $\mathrm{C}_{20} \mathrm{H}_{32} \mathrm{O}_{3}$, as indicated by HRESIMS $\left(\mathrm{m} / z 343.2250[\mathrm{M}+\mathrm{Na}]^{+}\right)$. Substitution of the hydroxy group of this compound was revealed by the IR absorption band at $v_{\max } 3419 \mathrm{~cm}^{-1}$ and ${ }^{13} \mathrm{C}$ NMR signals at $\delta_{\mathrm{C}} 73.0$ (C) and 71.6 $(\mathrm{CH})$. The two proton signals resonating at $\delta_{\mathrm{H}} 6.24$ and 5.75 (each $1 \mathrm{H}, \mathrm{d}, J=16.0 \mathrm{~Hz}$ ) were found to represent two olefinic protons correlated in the HSQC spectrum with the carbon signals at $\delta_{C} 123.7$ and 138.3 (each $\mathrm{CH}$ ), respectively, attributable to a trans 1,2-disubstituted double bond. Moreover, carbon signals at $\delta_{C} 146.0(\mathrm{C}), 131.9(\mathrm{C}), 127.6(\mathrm{CH}), 122.9(\mathrm{CH}), 64.7(\mathrm{C})$, and $61.3(\mathrm{CH})$ indicated the presence of two trisubstituted double bonds and a trisubstituted epoxide in 7 . The remaining ten carbons were assigned to five methyls, one $s p^{3}$ methine and four methylene groups. By NMR spectroscopic data comparison, it was found that this compound was the 13-hydroxy derivative of $\mathbf{1 0}$, isolated in this study and previously from $S$. gibberosa [16]. The hydroxy group at C-13 in 7 induced a significant upfield shift at $\mathrm{H}-13\left(\Delta \delta_{\mathrm{H}}-1.21 \mathrm{ppm}\right)$ and a downfield shift at $\mathrm{C}-14\left(\Delta \delta_{\mathrm{C}}+5.0 \mathrm{ppm}\right)$ relative to 10 . The structure of 7 was unambiguously determined by the extensive analysis of COSY and HMBC (Figure 2) and NOESY correlations (Figure 7). In addition, the appearance of the $1 \mathrm{H}$ double doublet signal of $\mathrm{H}-13$ $\left(\delta_{\mathrm{H}} 4.59,1 \mathrm{H}, \mathrm{dd}, J=8.0,8.0 \mathrm{~Hz}\right)$ was due to vicinal coupling with the olefinic $\mathrm{H}-14\left(\delta_{\mathrm{H}} 5.10,1 \mathrm{H}, \mathrm{d}\right.$, $J=8.0 \mathrm{~Hz})$ and the free proton of the hydroxy group at $\mathrm{C}-13\left(\delta_{\mathrm{H}} 1.74,1 \mathrm{H}, \mathrm{d}, J=8.0 \mathrm{~Hz}\right)$. Comparison of the splitting patterns of H-13 and H-14 of $7(\mathrm{~d}, J=8.0 \mathrm{~Hz})$ with those of known cembranoid $10(\mathrm{~d}$, $J=9.0 \mathrm{~Hz}$ ) suggested the same stereochemistry at C-13. The structure of klyflaccicembranol G (7) was thus established as $(4 S, 11 S, 12 S, 13 S, 2 E, 7 E, 14 Z)-4,13$-dihydroxy-11,12-epoxy-cembra-2,7,14-triene.

Klyflaccicembranol I (9) possessed the molecular formula $\mathrm{C}_{20} \mathrm{H}_{32} \mathrm{O}_{3}$, as revealed from the ESIMS $\left(m / z 343[\mathrm{M}+\mathrm{Na}]^{+}\right)$and NMR data (Tables 1 and 3$)$. The ${ }^{1} \mathrm{H}$ and ${ }^{13} \mathrm{C}$ NMR data demonstrated the characteristic features of non-lactonized cembranoids $\left(\mathrm{C}_{20}\right.$ signals, including those of five methyls) isolated previously from soft corals of the genus Sinularia and Sarcophyton [16-18,24,25]. By careful spectral comparison, it was found that the ${ }^{1} \mathrm{H}$ and ${ }^{13} \mathrm{C}$ NMR data of 9 were identical to those of 11,12-epoxy-13,14-dihydroxycembrene obtained by hydrolysis of flaccidoxide [26], including the magnitude and sign of optical rotation $[\alpha]_{\mathrm{D}}^{25}+124$.

Cytotoxicity of metabolites 1-6 and 8-10 against the growth of HT-29 (human colon adenocarcinoma), A549 (human lung adenocarcinoma), K562 (human erythromyeloblastoid leukemia), and P388 (mouse lymphatic leukemia) cell lines was evaluated. With the exception of inactive metabolites 1, 3, 5, and 10, all the other compounds exhibited variable potency against the tested cell lines (Table 4). Compounds 4 and 6 showed cytotoxicity against K562 and A549 (IC 5044.9 and $21.4 \mu \mathrm{M}$, respectively). Compound 8 was capable of affecting the growth of three cancer cell lines (A549, K562, and P388) in the range of $\mathrm{IC}_{50} 34.6-49.4 \mu \mathrm{M}$; however, it was found to be doubly-potent ( $\left.\mathrm{IC}_{50} 49.4 \mu \mathrm{M}\right)$ relative to the positive control fluorouracil ( $\mathrm{IC}_{50} 110 \mu \mathrm{M}$ ) against $\mathrm{A} 549$ cancer cells. Compound 2 was cytotoxic against two cell lines (A549 and K562), being 6.5-fold more potent than the positive control against the growth of A549. In addition, compound 9 was cytotoxic against another pair of cancer cells (HT-29 and P338), being very potent against P388. 
Table 4. Cytotoxicities ( $\left.\mathrm{IC}_{50} \mu \mathrm{M}\right)$ of compounds $\mathbf{1 - 6}$ and 8-10.

\begin{tabular}{|c|c|c|c|c|}
\hline Compound & HT-29 & A549 & K562 & P388 \\
\hline 1 & $-a$ & $-{ }^{a}$ & $--^{a}$ & $-a$ \\
\hline 2 & $-a$ & 16.5 & 34.6 & $-a$ \\
\hline 3 & $-a$ & $-a$ & $-a$ & $-a$ \\
\hline 4 & $-a$ & $-{ }^{a}$ & 44.9 & $-{ }^{a}$ \\
\hline 5 & $-a$ & $-{ }^{a}$ & $-a$ & $-^{a}$ \\
\hline 6 & $-{ }^{a}$ & 21.4 & $-{ }^{a}$ & $-{ }^{a}$ \\
\hline 8 & $-{ }^{a}$ & 49.4 & 47.4 & 34.6 \\
\hline 9 & 41.9 & $-{ }^{a}$ & $-{ }^{a}$ & 25.9 \\
\hline 10 & $-{ }^{a}$ & $-{ }^{a}$ & $-^{a}$ & $-a$ \\
\hline Fluorouracil & 8.5 & 110 & 31.5 & 5.5 \\
\hline
\end{tabular}

\section{NO inhibitory activity}

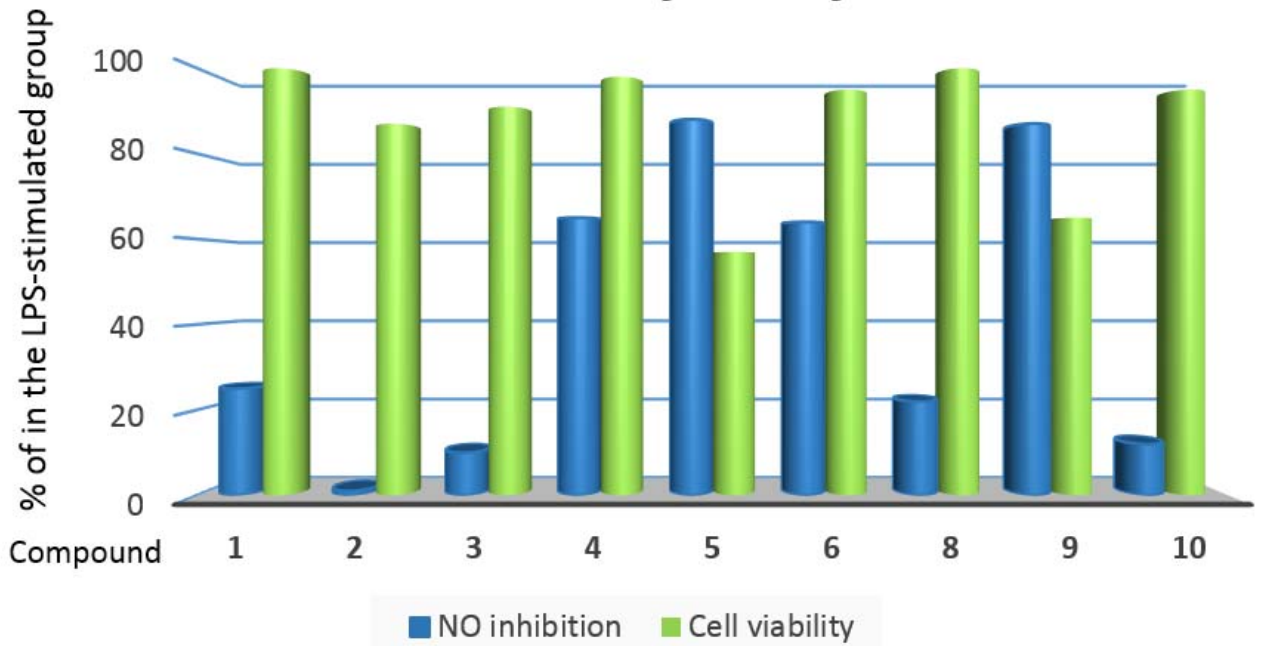

Figure 8. Inhibitory effects of compounds $\mathbf{1 - 6}$ and $\mathbf{8 - 1 0}$ at $50 \mu \mathrm{g} / \mathrm{mL}$ on nitric oxide (NO) production in lipopolysaccharide (LPS)-stimulated RAW264.7 cells.

The isolated compounds 1-6 and 8-10 also were evaluated in terms of their ability to suppress NO in LPS-activated RAW264.7 macrophages (Figure 8). The results showed that cembranoids $\mathbf{5}$ and 9 strongly inhibited $88 \%$ and $87 \%$ of NO production at $50 \mu \mathrm{g} / \mathrm{mL}$, respectively. However, compounds 4 and 6 at the same dose possessed moderate potency ( $65 \%$ and $64 \%$ NO inhibition), with $\mathrm{IC}_{50}$ values of 46.7 and $47.0 \mu \mathrm{g} / \mathrm{mL}$, respectively. The higher cell viability indexes attained by 4 and $6(98 \%$ and $95 \%$, respectively) relative to 5 and 9 represented an advantageous characteristic in addition to the NO inhibitory effect over 5 or $\mathbf{9}$. A positive control, curcumin, at $10 \mu \mathrm{g} / \mathrm{mL}$ succeeded under the same experimental conditions in reducing the $\mathrm{NO}$ level by $92.5 \%\left(\mathrm{IC}_{50} 6.3 \mu \mathrm{g} / \mathrm{mL}\right.$ ), in association with $98 \%$ retention of cell viability. With the exception of the inactive metabolite 2 , the rest of the tested compounds $(\mathbf{1}, 3,8$ and 10$)$ showed weak NO inhibitory activity $(12 \%-25 \%)$.

\section{Materials and Methods}

\subsection{General Procedures}

Optical rotations were measured on a JASCO P-1020 polarimeter (JASCO, Tokyo, Japan). IR spectra were recorded on a JASCO FT/IR-4100 spectrophotometer (JASCO). Ultraviolet spectra were recorded on a JASCO V-650 spectrophotometer. ESIMS and HRESIMS spectral data were recorded on a BRUKER APEX II mass spectrometer (Bruker, Bremen, Germany). The NMR spectra were recorded 
on a Varian Unity INOVA $500 \mathrm{FT}-\mathrm{NMR}$ at $500 \mathrm{MHz}$ for ${ }^{1} \mathrm{H}$ and $125 \mathrm{MHz}$ for ${ }^{13} \mathrm{C}$ or on a Varian 400 FT-NMR at $400 \mathrm{MHz}$ for ${ }^{1} \mathrm{H}$ and $100 \mathrm{MHz}$ for ${ }^{13} \mathrm{C}$ or on a Bruker AMX-300 FT-NMR at $300 \mathrm{MHz}$ for ${ }^{1} \mathrm{H}$ and $75 \mathrm{MHz}$ for ${ }^{13} \mathrm{C}$, in $\mathrm{CDCl}_{3}$ or $\mathrm{C}_{6} \mathrm{D}_{6}$ using TMS as internal standard ( $\delta$ in ppm, $J$ in $\mathrm{Hz}$ ). Silica gel 60 (Merck, 230-400 mesh), precoated silica gel plates (Merck, Darmstadt, Germany, Kieselgel $60 \mathrm{~F} 254,0.2 \mathrm{~mm}$ ) were used for open CC and analytical TLC analysis, respectively. Isolation by HPLC was performed by a Hitachi L-2455 instrument equipped with a reversed-phase (RP-18) column (GL Sciences Inc., Tokyo, Japan ODS-3, $5 \mu \mathrm{m}, 250 \times 20 \mathrm{~mm}$ ).

\subsection{Animal Material}

The soft coral Klyxum flaccidum Tixier-Durivault (Alcyoniidea) was collected by hand via SCUBA off the coast of Hsiao Liuchiu Island (22 $19^{\prime} 48^{\prime \prime}$ N 120 21 $55^{\prime \prime}$ E; Pingtung County), in October 2011, at a depth of 10-15 $\mathrm{m}$ along the coast of the island of Pratas, Taiwan. The species identification is based on three levels of morphological characters, i.e., colony shape, polyps' morphology and the morphology of sclerites in different parts of the coral colony, and then stored at $-20^{\circ} \mathrm{C}$ until extraction. A voucher sample (specimen no. LI6) was deposited at the Department of Marine Biotechnology and Resources, National Sun Yat-sen University (Kaohsiung, Taiwan). The organism was identified by Professor Chang-Feng Dai, Institute of Oceanography, National Taiwan University, Taipei 112, Taiwan.

\subsection{Extraction and Separation}

The frozen bodies of $K$. flaccidum ( $8.0 \mathrm{~kg}$, wet weight) were sliced and exhaustively extracted with EtOAc and filtered off. The solvent-free residue $(120 \mathrm{~g})$ was fractionated by silica gel column chromatography, using EtOAc- $n$-hexane (0:100 to 100:0, gradient) and then MeOH-EtOAc (0:100 to 100:0, gradient) as eluting solvents, in order to yield 26 fractions (F1 to F26). F8 eluted with EtOAc- $n$-hexane (1:2) was further isolated on silica gel, using EtOAc- $n$-hexane (1:3 to 2:3, stepwise) to yield $3(2.5 \mathrm{mg}), 2(1.5 \mathrm{mg})$, and $8(40.5 \mathrm{mg})$, respectively. F10 eluted with EtOAc- $n$-hexane (1:1) was separated on silica gel, using EtOAc- $n$-hexane (1:2) to give four subfractions F101-F104. F101 was isolated on RP-HPLC using $\mathrm{MeOH}-\mathrm{H}_{2} \mathrm{O}(3: 1)$ to give $4(10.2 \mathrm{mg}), \mathbf{9}(9.7 \mathrm{mg})$, and 10 (11.3 mg), respectively. F12 eluted with EtOAc- $n$-hexane (2:1) was re-chromatographed on silica gel column, using EtOAc- $n$-hexane (1:2-2:1), in order to give four subfractions F121-F124. F122 was isolated on RP-HPLC, using MeOH- $\mathrm{H}_{2} \mathrm{O}(15: 1)$ as a mobile phase, to yield $\mathbf{1}(1.8 \mathrm{mg}), \mathbf{5}(3.4 \mathrm{mg}), \mathbf{6}(2.1 \mathrm{mg})$, and $\mathbf{7}$ (3.2 mg).

\subsubsection{Klyflaccicembranol A (1)}

Colorless oil; $[\alpha]_{\mathrm{D}}^{25}+57.2\left(c 0.5, \mathrm{CHCl}_{3}\right)$; IR (neat) $v_{\max } 3445,2959,2924,2870,1456,1381,1118$, $1087,1064,850$ and $738 \mathrm{~cm}^{-1} ;{ }^{13} \mathrm{C}\left(100 \mathrm{MHz}, \mathrm{C}_{6} \mathrm{D}_{6}\right)$ and ${ }^{1} \mathrm{H}$ NMR $\left(400 \mathrm{MHz}, \mathrm{C}_{6} \mathrm{D}_{6}\right)$ data, see Tables 1 and 2, respectively; ESIMS $m / z 359\left[\mathrm{M}+\mathrm{Na}^{+}\right.$; HRESIMS $m / z 359.2196\left[\mathrm{M}+\mathrm{Na}^{+}\right.$(calcd. for $^{2}$ $\mathrm{C}_{20} \mathrm{H}_{32} \mathrm{O}_{4} \mathrm{Na}$, 359.2198).

\subsubsection{Klyflaccicembranol B (2)}

Colorless oil; $[\alpha]_{\mathrm{D}}^{25}+65.9\left(c 0.4, \mathrm{CHCl}_{3}\right)$; IR (neat) $v_{\max } 3443,2924,2856,1746,1457,1375$, and $1234 \mathrm{~cm}^{-1} ;{ }^{13} \mathrm{C}\left(125 \mathrm{MHz}, \mathrm{CDCl}_{3}\right)$ and ${ }^{1} \mathrm{H}$ NMR $\left(500 \mathrm{MHz}, \mathrm{CDCl}_{3}\right)$ data, see Tables 1 and 2, respectively; ESIMS $m / z 417\left[\mathrm{M}+\mathrm{Na}^{+} ;\right.$HRESIMS $m / z 417.2250[\mathrm{M}+\mathrm{Na}]^{+}$(calcd. for $\mathrm{C}_{22} \mathrm{H}_{34} \mathrm{O}_{6} \mathrm{Na}, 417.2253$ ).

\subsubsection{Klyflaccicembranol C (3)}

Colorless oil; $[\alpha]_{\mathrm{D}}^{25}+38.9\left(c 0.7, \mathrm{CHCl}_{3}\right)$; IR (neat) $v_{\max } 3450,2927,2858,1731,1455,1373,1240$ and $1016 \mathrm{~cm}^{-1} ;{ }^{13} \mathrm{C}\left(100 \mathrm{MHz}, \mathrm{CDCl}_{3}\right)$ and ${ }^{1} \mathrm{H}$ NMR $\left(400 \mathrm{MHz}_{2} \mathrm{CDCl}_{3}\right)$ data, see Tables 1 and 2, respectively; ESIMS $m / z 385[\mathrm{M}+\mathrm{Na}]^{+} ;$HRESIMS $m / z 385.2354[\mathrm{M}+\mathrm{Na}]^{+}$(calcd. for $\mathrm{C}_{22} \mathrm{H}_{34} \mathrm{O}_{4} \mathrm{Na}, 358.2355$ ). 


\subsubsection{Klyflaccicembranol D (4)}

Pale yellow oil; $[\alpha]_{\mathrm{D}}^{25}-1.51$ (c 3.17, $\mathrm{CHCl}_{3}$ ); IR (neat) $v_{\max } 3419,2953,2925,2867,1456,1375,977$, and $757 \mathrm{~cm}^{-1} ;{ }^{13} \mathrm{C}\left(100 \mathrm{MHz}, \mathrm{C}_{6} \mathrm{D}_{6}\right)$ and ${ }^{1} \mathrm{H}$ NMR $\left(400 \mathrm{MHz}, \mathrm{C}_{6} \mathrm{D}_{6}\right)$ data, see Tables 1 and 2, respectively; ESIMS $m / z 327[\mathrm{M}+\mathrm{Na}]^{+} ;$HRESIMS $m / z 327.2200[\mathrm{M}+\mathrm{Na}]^{+}$(calcd. for $\mathrm{C}_{20} \mathrm{H}_{32} \mathrm{O}_{2} \mathrm{Na}, 327.2198$ ).

\subsubsection{Klyflaccicembranol E (5)}

Colorless oil; $[\alpha]_{\mathrm{D}}^{25}-70.5$ (c 1.0, $\mathrm{CHCl}_{3}$ ); IR (neat) $v_{\max } 3408,2956,2924,2869,1455,1381,1002$, and $757 \mathrm{~cm}^{-1} ;{ }^{13} \mathrm{C}\left(100 \mathrm{MHz}, \mathrm{CDCl}_{3}\right)$ and ${ }^{1} \mathrm{H} \mathrm{NMR}\left(400 \mathrm{MHz}, \mathrm{CDCl}_{3}\right)$ data, see Tables 1 and 2, respectively; ESIMS $m / z 345[\mathrm{M}+\mathrm{Na}]^{+}$; HRESIMS $m / z 345.2404[\mathrm{M}+\mathrm{Na}]^{+}$(calcd. for $\mathrm{C}_{20} \mathrm{H}_{34} \mathrm{O}_{3} \mathrm{Na}$, 345.2406).

\subsubsection{Klyflaccicembranol F (6)}

Colorless oil; $[\alpha]_{\mathrm{D}}^{25}-32.0\left(\right.$ c 0.6, $\left.\mathrm{CHCl}_{3}\right)$; IR (neat) $v_{\max } 3392,2924,2855,1455$, and $1370 \mathrm{~cm}^{-1} ;{ }^{13} \mathrm{C}$ $\left(125 \mathrm{MHz}, \mathrm{CDCl}_{3}\right)$ and ${ }^{1} \mathrm{H}$ NMR $\left(500 \mathrm{MHz}, \mathrm{CDCl}_{3}\right)$ data, see Tables 1 and 3; ESIMS $m / z 345[\mathrm{M}+\mathrm{Na}]^{+}$; HRESIMS $m / z 345.2405[\mathrm{M}+\mathrm{Na}]^{+}$(calcd. for $\mathrm{C}_{20} \mathrm{H}_{34} \mathrm{O}_{3} \mathrm{Na}$, 345.2406).

\subsubsection{Klyflaccicembranol G (7)}

Colorless oil; $[\alpha]_{\mathrm{D}}^{25}+18.0\left(c\right.$ 1.0, $\left.\mathrm{CHCl}_{3}\right)$; IR (neat) $v_{\max } 3419,2953,2925,2867,1460,1375,977$ and $757 \mathrm{~cm}^{-1} ;{ }^{13} \mathrm{C}\left(100 \mathrm{MHz}, \mathrm{CDCl}_{3}\right)$ and ${ }^{1} \mathrm{H} \mathrm{NMR}\left(400 \mathrm{MHz}, \mathrm{CDCl}_{3}\right)$ data, see Tables 1 and 3, respectively; ESIMS $m / z 343[\mathrm{M}+\mathrm{Na}]^{+} ;$HRESIMS $m / z 343.2250[\mathrm{M}+\mathrm{Na}]^{+}$(calcd. for $\mathrm{C}_{20} \mathrm{H}_{32} \mathrm{O}_{3} \mathrm{Na}, 343.2249$ ).

\subsubsection{Klyflaccicembranol H (8)}

Colorless oil; $[\alpha]_{\mathrm{D}}^{25}+83.0$ (c 1.4, $\mathrm{CHCl}_{3}$ ); IR (neat) $v_{\max } 3310,3070,2964,2958,2931,2867,1730$, $1644,1460,1441,1371,1251$ and $1182 \mathrm{~cm}^{-1} ;{ }^{13} \mathrm{C}\left(100 \mathrm{MHz}, \mathrm{CDCl}_{3}\right)$ and ${ }^{1} \mathrm{H}$ NMR $\left(400 \mathrm{MHz}, \mathrm{CDCl}_{3}\right)$ data, see Tables 1 and 3, respectively; ${ }^{1} \mathrm{H}$ NMR $\left(\mathrm{CD}_{3} \mathrm{OD}, 500 \mathrm{MHz}\right) \delta_{\mathrm{H}} 5.65(1 \mathrm{H}, \mathrm{d}, J=2.0 \mathrm{~Hz}, \mathrm{H}-2)$, $5.37(1 \mathrm{H}, \mathrm{dd}, J=5.5,5.5 \mathrm{~Hz}, \mathrm{H}-7), 5.15(1 \mathrm{H}, \mathrm{d}, J=2.0 \mathrm{~Hz}, \mathrm{H}-13), 5.07(1 \mathrm{H}, \mathrm{ddd}, J=5.0,2.0,2.0 \mathrm{~Hz}$, $\mathrm{H}-14), 4.57(1 \mathrm{H}, \mathrm{d}, J=5.0 \mathrm{~Hz}, \mathrm{H}-3), 2.95(1 \mathrm{H}, \mathrm{dd}, J=7.5,1.5 \mathrm{~Hz}, \mathrm{H}-11), 2.21\left(2 \mathrm{H}, \mathrm{m}, \mathrm{H}_{2}-9\right), 2.19(1 \mathrm{H}, \mathrm{m}$, H-6), 2.13 (1H, m, H-15), 2.10 (1H, m, H-6), 1.93 (3H, s, Ac), 1.87 (1H, dd, J = 14.0, 9.5 Hz, H-5), 1.81 $(1 \mathrm{H}, \mathrm{m}, \mathrm{H}-10), 1.70(1 \mathrm{H}, \mathrm{m}, \mathrm{H}-10), 1.64(1 \mathrm{H}, \mathrm{dd}, J=14.0,8.0 \mathrm{~Hz}, \mathrm{H}-5), 1.60\left(3 \mathrm{H}, \mathrm{s}, \mathrm{H}_{3}-19\right), 1.39$ (3H, s, $\left.\mathrm{H}_{3}-20\right), 1.10\left(3 \mathrm{H}, \mathrm{dd}, J=7.0 \mathrm{~Hz}, \mathrm{H}_{3}-17\right), 1.06\left(3 \mathrm{H}, \mathrm{dd}, J=7.0 \mathrm{~Hz}, \mathrm{H}_{3}-16\right), 0.96\left(3 \mathrm{H}, \mathrm{s}, \mathrm{H}_{3}-18\right) ;{ }^{13} \mathrm{C} \mathrm{NMR}$ $\left(\mathrm{CD}_{3} \mathrm{OD}, 125 \mathrm{MHz}\right) \delta_{\mathrm{C}} 171.7$ (C, 13-OAc), $148.4(\mathrm{C}, \mathrm{C}-1), 133.2(\mathrm{C}, \mathrm{C}-8), 128.2(\mathrm{CH}, \mathrm{C}-7), 122.9(\mathrm{CH}$, C-2), 90.6 (CH, C-3), 86.2 (CH, C-14), 75.2 (C, C-4), 74.2 (CH, C-13), 62.3 (C, C-12), 61.0 (CH, C-11), 42.1 $\left(\mathrm{CH}_{2}, \mathrm{C}-5\right), 37.7\left(\mathrm{CH}_{2}, \mathrm{C}-9\right), 25.6\left(\mathrm{CH}_{2}, \mathrm{C}-10\right), 22.7\left(\mathrm{CH}_{2}, \mathrm{C}-6\right), 25.7(\mathrm{CH}, \mathrm{C}-15), 22.7\left(\mathrm{CH}_{3}, \mathrm{C}-6\right), 22.7$ $\left(\mathrm{CH}_{3}, \mathrm{C}-18\right), 22.6\left(\mathrm{CH}_{3}, \mathrm{C}-16\right), 21.3\left(\mathrm{CH}_{3}, \mathrm{C}-17\right), 20.6\left(\mathrm{CH}_{3}, 13-\mathrm{OAc}\right), 16.8\left(\mathrm{CH}_{3}, \mathrm{C}-19\right), 16.2\left(\mathrm{CH}_{3}, \mathrm{C}-20\right)$; ESIMS $m / z 401\left[\mathrm{M}+\mathrm{Na}^{+}, 385\left[\mathrm{M}-\mathrm{O}+\mathrm{Na}^{+}, 325[\mathrm{M}-\mathrm{AcOH}-\mathrm{O}+\mathrm{Na}]^{+} ; \operatorname{EIMS} m / z 379[\mathrm{M}+\mathrm{H}]^{+}\right.\right.$, $361\left[\mathrm{M}-\mathrm{H}_{2} \mathrm{O}\right]^{+}, 318[\mathrm{M}-\mathrm{AcOH}]^{+}, 300\left[\mathrm{M}-\mathrm{AcOH}-\mathrm{H}_{2} \mathrm{O}\right]^{+} ;$HRESIMS $m / z 378.2404[\mathrm{M}]^{+}$(calcd. for $\mathrm{C}_{22} \mathrm{H}_{34} \mathrm{O}_{5}, 378.2406$ ).

\subsubsection{Klyflaccicembranol I (9)}

Colorless oil; $[\alpha]_{\mathrm{D}}^{25}+124.0$ (c 2.7, $\left.\mathrm{CHCl}_{3}\right)$; IR (neat) $v_{\max } 3487,3275,2955,2933,2868,1732,1644$, $1453,1370,1247$ and $1183 \mathrm{~cm}^{-1} ;{ }^{13} \mathrm{C}\left(100 \mathrm{MHz}, \mathrm{C}_{6} \mathrm{D}_{6}\right)$ and ${ }^{1} \mathrm{H}$ NMR $\left(400 \mathrm{MHz}, \mathrm{C}_{6} \mathrm{D}_{6}\right)$ data, see Tables 1 and 3 , respectively; ESIMS $m / z 343[\mathrm{M}+\mathrm{Na}]^{+}$.

\subsubsection{Hydrolysis of Klyflaccicembranol H (8)}

A solution of $8(3.2 \mathrm{mg}, 8.12 \mu \mathrm{mol})$ in $\mathrm{MeOH}(2.0 \mathrm{~mL})$ was stirred with $\mathrm{K}_{2} \mathrm{CO}_{3}(30 \mathrm{mg})$ overnight at room temperature. The reaction mixture was diluted with distilled water $(3.0 \mathrm{~mL})$ and followed by extraction with $\mathrm{CH}_{2} \mathrm{Cl}_{2}$. The organic extract was then purified on short silica gel CC, using $25 \%$ EtOAc in $n$-hexane as an eluting solvent, to afford $\mathbf{1}(2.4 \mathrm{mg}, 6.82 \mu \mathrm{mol}, 84 \%$ yield $) .1$ : colorless oil; ${ }^{1} \mathrm{H}$ NMR $\left(\mathrm{CDCl}_{3}, 300 \mathrm{MHz}\right) . \delta_{\mathrm{H}} 5.64(1 \mathrm{H}, \mathrm{br} \mathrm{s}, \mathrm{H}-2), 5.32(1 \mathrm{H}, \mathrm{dd}, J=5.5,5.5 \mathrm{~Hz}, \mathrm{H}-7), 3.81(1 \mathrm{H}, \mathrm{d}, J=1.8 \mathrm{~Hz}$, H-13), $4.92(1 \mathrm{H}$, br d, J = 5.5 Hz, H-14), $4.57(1 \mathrm{H}, \mathrm{d}, J=5.5 \mathrm{~Hz}, \mathrm{H}-3), 3.12(1 \mathrm{H}, \mathrm{dd}, J=9.5,3.6 \mathrm{~Hz}, \mathrm{H}-11)$, 
$2.20\left(2 \mathrm{H}, \mathrm{m}, \mathrm{H}_{2}-9\right), 2.13\left(2 \mathrm{H}, \mathrm{m}, \mathrm{H}_{2}-6\right), 2.37$ (1H, septet, $\left.J=6.9 \mathrm{~Hz}, \mathrm{H}-15\right), 1.89(1 \mathrm{H}, \mathrm{m}, \mathrm{H}-5 \mathrm{a}), 1.83(2 \mathrm{H}$, $\left.\mathrm{m}, \mathrm{H}_{2}-10\right), 1.65(1 \mathrm{H}, \mathrm{m}, \mathrm{H}-5 \mathrm{~b}), 1.59\left(3 \mathrm{H}, \mathrm{s}, \mathrm{H}_{3}-19\right), 1.36$ (3H, s, $\left.\mathrm{H}_{3}-20\right), 1.10\left(3 \mathrm{H}, \mathrm{dd}, J=6.9 \mathrm{~Hz}, \mathrm{H}_{3}-17\right)$, $1.08\left(3 \mathrm{H}, \mathrm{dd}, J=6.9 \mathrm{~Hz}, \mathrm{H}_{3}-16\right), 1.01\left(3 \mathrm{H}, \mathrm{s}, \mathrm{H}_{3}-18\right) ;{ }^{13} \mathrm{C} \mathrm{NMR}\left(\mathrm{CDCl}_{3}, 75 \mathrm{MHz}\right) \delta_{\mathrm{C}} 148.4(\mathrm{C}, \mathrm{C}-1), 132.8$ (C, C-8), 126.8 (CH, C-7), 122.9 (CH, C-2), 89.6 (CH, C-3), 85.6 (CH, C-14), 74.9 (C, C-4), 72.6 (CH, C-13), $62.4(\mathrm{C}, \mathrm{C}-12), 60.3(\mathrm{CH}, \mathrm{C}-11), 41.6\left(\mathrm{CH}_{2}, \mathrm{C}-5\right), 36.9\left(\mathrm{CH}_{2}, \mathrm{C}-9\right), 24.8\left(\mathrm{CH}_{2}, \mathrm{C}-10\right), 22.1\left(\mathrm{CH}_{2}, \mathrm{C}-6\right), 26.6$ (CH, C-15), $22.1\left(\mathrm{CH}_{3}, \mathrm{C}-6\right), 22.7\left(\mathrm{CH}_{3}, \mathrm{C}-18\right), 22.4\left(\mathrm{CH}_{3}, \mathrm{C}-16\right), 21.4\left(\mathrm{CH}_{3}, \mathrm{C}-17\right), 16.9\left(\mathrm{CH}_{3}, \mathrm{C}-19\right), 15.7$ $\left(\mathrm{CH}_{3}, \mathrm{C}-20\right)$.

\subsubsection{Preparation of (S)- and (R)-MTPA Esters of $\mathbf{1}$}

To a solution of $\mathbf{1}(1.1 \mathrm{mg}, 3.1 \mu \mathrm{mol})$ in pyridine $(50 \mu \mathrm{L}), R-(-)$-MTPA chloride $(5 \mu \mathrm{L})$ was added and allowed to react overnight at room temperature. The reaction was terminated by the addition of $1.0 \mathrm{~mL}$ of water, and then processed as previously described [27] to yield the (S)-MTPA ester 1a $(1.2 \mathrm{mg}, 2.1 \mu \mathrm{mol}, 67.7 \%)$. Similarly, the correspondent $(R)$-MTPA ester $\mathbf{1 b}$ was also obtained from the reaction of $S-(+)-M T P A$ chloride with $1 .{ }^{1} \mathrm{H}$ NMR $\left(\mathrm{CDCl}_{3}, 300 \mathrm{MHz}\right)$ of $1 \mathrm{a}: \delta_{\mathrm{H}} 5.496(1 \mathrm{H}, \mathrm{br} \mathrm{s}, \mathrm{H}-2)$, $5.341(1 \mathrm{H}, \mathrm{br} \mathrm{s}, \mathrm{H}-13), 5.185(1 \mathrm{H}, \mathrm{dd}, J=4.5,4.5 \mathrm{~Hz}, \mathrm{H}-7), 5.030(1 \mathrm{H}, \mathrm{br} \mathrm{d}, J=4.5 \mathrm{~Hz}, \mathrm{H}-14), 4.324(1 \mathrm{H}$, br d, $J=4.5 \mathrm{~Hz}, \mathrm{H}-3), 2.609(1 \mathrm{H}, \mathrm{m}, \mathrm{H}-11), 2.177(1 \mathrm{H}, \mathrm{m}, \mathrm{H}-15), 2.100\left(4 \mathrm{H}, \mathrm{m}, \mathrm{H}_{2}-6\right.$ and $\left.\mathrm{H}_{2}-9\right), 1.985$ $(1 \mathrm{H}, \mathrm{m}, \mathrm{H}-5 \alpha), 1.825(1 \mathrm{H}, \mathrm{m}, \mathrm{H}-5 \beta), 1.666\left(2 \mathrm{H}, \mathrm{m}, \mathrm{H}_{2}-10\right), 1.536\left(3 \mathrm{H}, \mathrm{s}, \mathrm{H}_{3}-19\right), 1.387\left(3 \mathrm{H}, \mathrm{s}, \mathrm{H}_{3}-20\right)$, $1.097\left(3 \mathrm{H}, \mathrm{d}, J=6.9 \mathrm{~Hz}, \mathrm{H}_{3}-17\right), 1.040\left(3 \mathrm{H}, \mathrm{d}, J=6.9 \mathrm{~Hz}, \mathrm{H}_{3}-16\right), 0.962\left(3 \mathrm{H}, \mathrm{s}, \mathrm{H}_{3}-18\right) .{ }^{1} \mathrm{H} \mathrm{NMR}\left(\mathrm{CDCl}_{3}\right.$, $300 \mathrm{MHz})$ of $1 \mathbf{b}: \delta_{\mathrm{H}} 5.639(1 \mathrm{H}, \mathrm{br} \mathrm{s}, \mathrm{H}-2), 5.347(1 \mathrm{H}, \mathrm{br} \mathrm{s}, \mathrm{H}-13), 5.223(1 \mathrm{H}, \mathrm{dd}, J=4.5,4.5 \mathrm{~Hz}, \mathrm{H}-7), 5.075$ $(1 \mathrm{H}, \mathrm{br} \mathrm{d}, J=4.5 \mathrm{~Hz}, \mathrm{H}-14), 4.542(1 \mathrm{H}, \mathrm{br} \mathrm{d}, J=4.5 \mathrm{~Hz}, \mathrm{H}-3), 2.623(1 \mathrm{H}, \mathrm{m}, \mathrm{H}-11), 2.176(1 \mathrm{H}, \mathrm{m}, \mathrm{H}-15)$, $2.111\left(4 \mathrm{H}, \mathrm{m}, \mathrm{H}_{2}-6\right.$ and $\left.\mathrm{H}_{2}-9\right), 1.994(1 \mathrm{H}, \mathrm{m}, \mathrm{H}-5 \alpha), 1.858(1 \mathrm{H}, \mathrm{m}, \mathrm{H}-5 \beta), 1.637\left(2 \mathrm{H}, \mathrm{m}, \mathrm{H}_{2}-10\right), 1.543$ $\left(3 \mathrm{H}, \mathrm{s}, \mathrm{H}_{3}-19\right), 1.382\left(3 \mathrm{H}, \mathrm{s}, \mathrm{H}_{3}-20\right), 1.122\left(3 \mathrm{H}, \mathrm{d}, J=6.9 \mathrm{~Hz}, \mathrm{H}_{3}-17\right), 1.057\left(3 \mathrm{H}, \mathrm{d}, J=6.9 \mathrm{~Hz}, \mathrm{H}_{3}-16\right)$, $1.003\left(3 \mathrm{H}, \mathrm{s}, \mathrm{H}_{3}-18\right)$.

\subsection{Cytotoxicity Assay}

Cancer cell (HT-29, A549, K562, and P388) lines were purchased from the American Type Culture Collection (ATCC). Evaluation of cytotoxicity for the isolated metabolites from K. flaccidum was performed according to Alamar Blue assay [14,15].

\subsection{Nitric Oxide Inhibitory Assay}

The inhibitory activity of isolated compounds on nitric oxide (NO) production by murine RAW 264.7 macrophage cells was assessed according to Griess reaction. Briefly, cells were cultured in 96-well plates for $1 \mathrm{~h}$. The cells were challenged with LPS $(5 \mu \mathrm{g} / \mathrm{mL})$ and test samples for $48 \mathrm{~h}$. The culture supernatant $(100 \mu \mathrm{L})$ were reacted then with Griess reagent $(1: 1$ mixture of $0.1 \%$ $N$-(1-naphthyl) ethylene-diamine dihydrochloride in water and $1 \%$ sulfanilamide in $5 \%$ phosphoric acid, $100 \mu \mathrm{L}$ ) in a 96-well plate, and absorbance was measured using the ELISA reader at $540 \mathrm{~nm}$ [28,29].

\section{Conclusions}

For the first time, cembranoid-based compounds were isolated and identified from the soft corals of genus Klyxum by this study. Five metabolites (klyflaccicembranols B, D, F, H, and I) exhibited variable activities against a limited panel of cancer cell lines while klyflaccicembranols D-F and I showed strong anti-inflammatory effect through inhibition of NO production in LPS-stimulated RAW264.7 macrophages.

Supplementary Materials: HRESIMS, ${ }^{1} \mathrm{H}$, and ${ }^{13} \mathrm{C}$ spectra of new compounds $\mathbf{1 - 9}$ are available online at www. mdpi.com/1660-3397/15/1/23/s1. Figure S1: HRESIMS spectrum of 1, Figure S2: ${ }^{1} \mathrm{H}$ NMR spectrum of $\mathbf{1}$ in $\mathrm{C}_{6} \mathrm{D}_{6}$ at $400 \mathrm{MHz}$, Figure S3: ${ }^{13} \mathrm{C}$ NMR spectrum of 1 in $\mathrm{C}_{6} \mathrm{D}_{6}$ at $100 \mathrm{MHz}$, Figure S4: HRESIMS spectrum of 2, Figure S5: ${ }^{1} \mathrm{H}$ NMR spectrum of 2 in $\mathrm{CDCl}_{3}$ at $500 \mathrm{MHz}$, Figure S6: ${ }^{13} \mathrm{C}$ NMR spectrum of 2 in $\mathrm{CDCl}_{3}$ at $125 \mathrm{MHz}$, Figure S7: HRESIMS spectrum of 3, Figure S8: ${ }^{1} \mathrm{H}$ NMR spectrum of 3 in $\mathrm{CDCl}_{3}$ at $400 \mathrm{MHz}$, Figure S9: ${ }^{13} \mathrm{C}$ NMR spectrum of 3 in $\mathrm{CDCl}_{3}$ at $100 \mathrm{MHz}$, Figure S10: HRESIMS spectrum of 4, Figure S11: ${ }^{1} \mathrm{H}$ NMR spectrum of 4 in $\mathrm{C}_{6} \mathrm{D}_{6}$ at $400 \mathrm{MHz}$, Figure S12: ${ }^{13} \mathrm{C}$ NMR spectrum of 4 in $\mathrm{C}_{6} \mathrm{D}_{6}$ at $100 \mathrm{MHz}$, Figure S13: HRESIMS spectrum 
of 5, Figure S14: ${ }^{1} \mathrm{H}$ NMR spectrum of 5 in $\mathrm{CDCl}_{3}$ at $400 \mathrm{MHz}$, Figure S15: ${ }^{13} \mathrm{C}$ NMR spectrum of 5 in $\mathrm{CDCl}_{3}$ at $100 \mathrm{MHz}$, Figure S16: HRESIMS spectrum of 6, Figure S17: ${ }^{1} \mathrm{H}$ NMR spectrum of 6 in $\mathrm{CDCl}_{3}$ at $500 \mathrm{MHz}$, Figure S18: ${ }^{13} \mathrm{C}$ NMR spectrum of 6 in $\mathrm{CDCl}_{3}$ at $125 \mathrm{MHz}$, Figure S19: HRESIMS spectrum of 7, Figure S20: ${ }^{1} \mathrm{H}$ NMR spectrum of 7 in $\mathrm{CDCl}_{3}$ at $400 \mathrm{MHz}$, Figure S21: ${ }^{13} \mathrm{C} \mathrm{NMR}$ spectrum of 7 in $\mathrm{CDCl}_{3}$ at $100 \mathrm{MHz}$, Figure S22: HRESIMS spectrum of 8, Figure S23: ${ }^{1} \mathrm{H}$ NMR spectrum of 8 in $\mathrm{CDCl}_{3}$ at $400 \mathrm{MHz}$, Figure S24: ${ }^{13} \mathrm{C}$ NMR spectrum of 8 in $\mathrm{CDCl}_{3}$ at $100 \mathrm{MHz}$, Figure S25: ESIMS spectrum of 9, Figure S26: ${ }^{1} \mathrm{H}$ NMR spectrum of 9 in $\mathrm{C}_{6} \mathrm{D}_{6}$ at $400 \mathrm{MHz}$, Figure S27: ${ }^{13} \mathrm{C}$ NMR spectrum of 9 in $\mathrm{C}_{6} \mathrm{D}_{6}$ at $100 \mathrm{MHz}$.

Acknowledgments: This work was supported by grants from the Ministry of Science and Technology (MOST 102-2628-B-110-002-MY2 and 104-2320-B-110-001-MY2), Aim for the Top University Program (05C030205) from the Ministry of Education of Taiwan and the National Sun Yat-sen University-Kaohsiung Medical University (NSYSU-KMU) Joint Research Project (NSYSUKMU 105-I008) of Taiwan awarded to J.-H.S. Partial financial support from the Taiwan Protein Project (MOST 105-0210-01-12-01) to J.-H.S. is also acknowledged.

Author Contributions: Jyh-Horng Sheu designed and guided the whole experiment. Atallah F. Ahmed contributed to structure elucidation and manuscript preparation. Chia-Ruei Tsai isolated the compounds and performed data acquisition and structure elucidation. Chiung-Yao Huang performed the structure elucidation and cytotoxicity assay. Sheng-Yang Wang performed the nitric oxide inhibitory assay.

Conflicts of Interest: The authors declare no conflict of interest.

\section{References}

1. Blunt, J.W.; Copp, B.R.; Hu, W.P.; Munro, M.H.; Northcote, P.T.; Prinsep, M.R. Marine natural products. Nat. Prod. Rep. 2016, 33, 382-431. [CrossRef] [PubMed]

2. Chen, B.W.; Chao, C.H.; Su, J.H.; Wen, Z.H.; Sung, P.J.; Sheu, J.H. Anti-inflammatory eunicellin-based diterpenoids from the cultured soft coral Klyxum simplex. Org. Biomol. Chem. 2010, 8, 2363-2366. [CrossRef] [PubMed]

3. Oh, D.C.; Strangman, W.K.; Kauffman, C.A.; Jensen, P.R.; Fenical, W. Thalassospiramides A and B, immunosuppressive peptides from the marine bacterium Thalassospira sp. Org. Lett. 2007, 9, 1525-1528. [CrossRef] [PubMed]

4. Kijjoa, A.; Sawangwong, P. Drugs and cosmetics from the sea. Mar. Drugs 2004, 2, 73-82. [CrossRef]

5. Chill, L.; Berrer, N.; Benayahu, Y.; Kashman, Y. Eunicellin diterpenes from two Kenyan soft corals. J. Nat. Prod. 2005, 68, 19-25. [CrossRef] [PubMed]

6. Wu, S.L.; Su, J.H.; Wen, Z.H.; Hsu, C.H.; Chen, B.W.; Dai, C.F.; Kuo, Y.H.; Sheu, J.H. Simplexins A-I, eunicellin-based diterpenoids from the soft coral Klyxum simplex. J. Nat. Prod. 2009, 72, 994-1000. [CrossRef] [PubMed]

7. Wu, S.L.; Su, J.H.; Lu, Y.; Chen, B.W.; Huang, C.Y.; Wen, Z.H.; Kuo, Y.H.; Sheu, J.H. Simplexins J-O, eunicellin-based diterpenoids from a Dongsha Atoll soft coral Klyxum simplex. Bull. Chem. Soc. Jpn. 2011, 84, 626-632. [CrossRef]

8. Chen, B.W.; Chao, C.H.; Su, J.H.; Tsai, C.W.; Wang, W.H.; Wen, Z.H.; Huang, C.Y.; Sung, P.J.; Wu, Y.C.; Sheu, J.H. Klysimplexins I-T, eunicellin-based diterpenoids from the cultured soft coral Klyxum simplex. Org. Biomol. Chem. 2011, 9, 834-844. [CrossRef] [PubMed]

9. Hsu, F.J.; Chen, B.W.; Wen, Z.H.; Huang, C.Y.; Dai, C.F.; Su, J.H.; Wu, Y.C.; Sheu, J.H. Klymollins A-H, bioactive eunicellin-based diterpenoids from the formosan soft coral Klyxum molle. J. Nat. Prod. 2011, 74, 2467-2471. [CrossRef] [PubMed]

10. Chang, F.Y.; Hsu, F.J.; Tai, C.J.; Wei, W.C.; Yang, N.S.; Sheu, J.H. Klymollins T-X, bioactive eunicellin-based diterpenoids from the soft coral Klyxum molle. Mar. Drugs 2014, 12, 3060-3071. [CrossRef] [PubMed]

11. Chen, B.W.; Wu, Y.C.; Chiang, M.Y.; Su, J.H.; Wang, W.H.; Fan, T.Y.; Sheu, J.H. Eunicellin-based diterpenoids from the cultured soft coral Klyxum simplex. Tetrahedron 2009, 65, 7016-7022. [CrossRef]

12. Tseng, W.R.; Huang, C.Y.; Tsai, Y.Y.; Lin, Y.S.; Hwang, T.L.; Su, J.H.; Sung, P.J.; Dai, C.F.; Sheu, J.H. New cytotoxic and anti-inflammatory steroids from the soft coral Klyxum flaccidum. Bioorg. Med. Chem. Lett. 2016, 26, 3253-3257. [CrossRef] [PubMed]

13. Tsai, C.R.; Huang, C.Y.; Chen, B.W.; Tsai, Y.Y.; Shih, S.P.; Hwang, T.L.; Dai, C.F.; Wang, S.Y.; Sheu, J.H. New bioactive steroids from the soft coral Klyxum flaccidum. RSC Adv. 2015, 5, 12546-12554. [CrossRef]

14. O'Brien, J.; Wilson, I.; Orton, T.; Pognan, F. Investigation of the Alamar Blue (resazurin) fluorescent dye for the assessment of mammalian cell cytotoxicity. Eur. J. Biochem. 2000, 267, 5421-5426. [CrossRef] [PubMed] 
15. Nakayama, G.R.; Caton, M.C.; Nova, M.P.; Parandoosh, Z. Assessment of the Alamar Blue assay for cellular growth and viability in vitro. J. Immunol. Methods 1997, 204, 205-208. [CrossRef]

16. Ahmed, A.F.; Wen, Z.H.; Su, J.H.; Hsieh, Y.T.; Wu, Y.C.; Hu, W.P.; Sheu, J.H. Oxygenated cembranoids from a Formosan soft coral Sinularia gibberosa. J. Nat. Prod. 2008, 71, 179-185. [CrossRef] [PubMed]

17. Kobayashi, M.; Nakagawa, T.; Mitsuhashi, H. Marine terpenes and terpenoids. I. Structures of four cembrane-type diterpenes: Sarcophytol-A, sarcophytol-A acetate sarcophytol-B, and sarcophytonin-A, from the soft coral, Sarcophyton glaucum. Chem. Pharm. Bull. 1979, 27, 2382-2387. [CrossRef]

18. Duh, C.Y.; Hou, R.S. Cytotoxic cembranoids from the soft corals Sinularia gibberosa and Sarcophyton trocheliophorum. J. Nat. Prod. 1996, 59, 595-598. [CrossRef]

19. Barfield, M.; Spear, R.J.; Sternhell, S. Interproton spin-spin coupling across a dual path in 2,5-dihydrofurans and phthalans. J. Am. Chem. Soc. 1975, 97, 5160-5167. [CrossRef]

20. Ohtani, I.; Kusumi, T.; Kashman, Y.; Kakisawa, H. High-field FT NMR application of Mosher's method. The absolute configurations of marine terpenoids. J. Am. Chem. Soc. 1991, 113, 4092-4096. [CrossRef]

21. Randazzo, A.; Bifulco, G.; Giannini, C.; Bucci, M.; Debitus, C.; Cirino, G.; Gomez-Paloma, L. Halipeptins A and B: Two novel potent anti-inflammatory cyclic depsipeptides from the Vanuatu marine sponge Haliclona species. J. Am. Chem. Soc. 2001, 123, 10870-10876. [CrossRef] [PubMed]

22. Kobayashi, M.; Kondo, K.; Osabe, K.; Mitsuhashi, H. Marine terpenes and terpenoids. V. Oxidation of sarcophytol A, a potent anti-tumor-promoter from the soft coral Sarcophyton glaucum. Chem. Pharm. Bull. 1988, 36, 2331-2341. [CrossRef] [PubMed]

23. Lin, S.T.; Wang, S.K.; Duh, C.Y. Cembranoids from the Dongsha Atoll soft coral Lobophytum crassum. Mar. Drugs 2011, 9, 2705-2716. [CrossRef] [PubMed]

24. Kobayashi, M.; Hirase, T. Marine Terpenes and Terpenoids. XI: Structures of new dihydrofuranocembranoids isolated from a Sarcophyton sp. Soft coral of Okinawa. Chem. Pharm. Bull. 1990, 38, 2442-2445. [CrossRef]

25. Ahmed, A.F.; Tai, S.H.; Wen, Z.H.; Su, J.H.; Wu, Y.C.; Hu, W.P.; Sheu, J.H. A C-3 methylated isocembranoid and 10-oxocembranoids from a formosan soft coral, Sinularia grandilobata. J. Nat. Prod. 2008, 71, 946-951. [CrossRef] [PubMed]

26. Kashman, Y.; Carmely, S.; Groweiss, A. Further cembranoid derivatives from the Red Sea soft corals Alcyonium flaccidum and Lobophytum crassum. J. Org. Chem. 1981, 46, 3592-3596. [CrossRef]

27. Huang, H.C.; Ahmed, A.F.; Su, J.H.; Chao, C.H.; Wu, Y.C.; Chiang, M.Y.; Sheu, J.H. Crassolides A-F, cembranoids with a trans-fused lactone from the soft coral Sarcophyton crassocaule. J. Nat. Prod. 2006, 69, 1554-1559. [CrossRef] [PubMed]

28. Bryan, N.S.; Grisham, M.B. Methods to detect nitric oxide and its metabolites in biological samples. Free Radic. Biol. Med. 2007, 43, 645-657. [CrossRef] [PubMed]

29. Hsieh, Y.H.; Kuo, P.M.; Chien, S.C.; Shyur, L.F.; Wang, S.Y. Effects of Chamaecyparis formosensis Matasumura extractives on lipopolysaccharide-induced release of nitric oxide. Phytomedicine 2007, 14, 675-680. [CrossRef] [PubMed]

(C) 2017 by the authors; licensee MDPI, Basel, Switzerland. This article is an open access article distributed under the terms and conditions of the Creative Commons Attribution (CC BY) license (http:// creativecommons.org/licenses/by/4.0/). 